\title{
Magmatic evolution of compositionally heterogeneous monogenetic Cenozoic Strzelin Volcanic Field (Fore-Sudetic Block, SW Poland)
}

\author{
Marek AWDANKIEWICZ ${ }^{*}$, Vladislav RAPPRICH², Jitka MÍKOVÁ \\ ${ }^{1}$ University of Wrocław, Institute of Geological Sciences, Department of Mineralogy and Petrology, ul. Cybulskiego 30, 50-205 Wroclaw, \\ Poland; marek.awdankiewicz@uwr.edu.pl \\ ${ }^{2}$ Czech Geological Survey, Klárov 3, 11821 Prague 1, Czech Republic \\ * Corresponding author
}

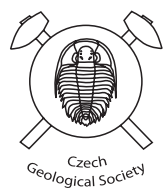

Erosional remnants of the Miocene Strzelin Volcanic Field in SW Poland were studied in terms of volcanology, petrology and $\mathrm{Sr}-\mathrm{Nd}-\mathrm{Pb}$ isotope geochemistry with the aim to identify the reasons for compositional variability of monogenetic volcanoes. The obtained data suggest that a heterogeneous mantle peridotite (with mixed DM/HIMU signature) was the dominant source of magmas. Partial melting and segregation of magmas in diapirically rising asthenosphere occurred within the garnet stability field. The source heterogeneity was the basic cause that controlled the compositional variability of the primary magmas, and also influenced the subsequent differentiation processes and eruptive styles. On the surface, additional role was played by variable environments (i.e. phreatomagmatic eruptions in water-saturated environments). More fertile mantle domains, with prevailing HIMU component, released melts deeper, at lower degrees of partial melting and small magma batches were formed. These nephelinitic magmas underwent only limited fractional crystallization en route to the surface and erupted with low explosivity as lava flows. In contrast, less fertile mantle domains, dominated by the DM component, released melts at higher degrees of partial melting at a shallower depth. This resulted in a more sustained magma supply that further enhanced the development of shallow-level magmatic systems, with more advanced and complex differentiation: larger degrees of fractional crystallization as well as replenishment by new batches of primitive magma. The resulting basaltic and trachybasaltic volcanoes showed a greater diversity of eruptive styles, including effusive and variably explosive eruptions.

Keywords: Strzelin Volcanic Field, monogenetic basaltic volcanism, alkaline magmatism, Sr-Nd-Pb isotopes, magma sources Received: 1 June, 2016; accepted: 20 December, 2016; handling editor: E. Jelinek

The online version of this article (doi: 10.3190/jgeosci.221) contains supplementary electronic material.

\section{Introduction}

Mafic, monogenetic volcanic fields, comprised of tens to hundreds of small pyroclastic cones and craters with associated lavas, are amongst the most common manifestations of continental basaltic (sensu lato) volcanism (Cas and Wright 1987). The cumulative volumes of magma erupted in such fields may reach that of much larger polygenetic volcanoes (Connor and Conway 2000). However, the individual monogenetic volcanoes are of low volume, short-lived and are, generally, linked to the rise and eruption of small batches of basaltic magma with the formation of relatively simple volcanic edifices. In recent years the evolution of eruptive styles and even complex eruptive scenarios were recognized in many monogenetic volcanoes (Kereszturi and Németh 2012 and references therein). Individual volcanic systems within fields of monogenetic volcanoes usually show some geochemical differences (e.g., in the Eifel Volcanic Fields: Mertes and Schmincke 1985) and some recent studies demonstrate also that even a single monogenetic volcano may display a strong compositional variation. These relatively rare cases have been linked to differentiation in complex, shallow-level magmatic systems (Brenna et al. 2011), but also the differences in the source characteristics and the degree and depth of partial melting (Needham et al. 2011; McGee et al. 2012) or source metasomatism (Augustín-Flores et al. 2011) may directly influence the erupted compositions and eruptive behaviour of monogenetic volcanoes. Thus, some of the key problems in the studies of monogenetic volcanism include the relative roles of deep- vs. shallow-level controls on magma compositions and styles of volcanism, as well as the links between magma origin and evolution, and the shallowlevel emplacement and eruptive processes.

Mafic and bimodal, intraplate anorogenic volcanic activity occurred around the Mediterranean Sea and adjacent parts of Europe and Northern Africa in Cenozoic to sub-Recent (Lustrino and Wilson 2007). The northern part of this Circum-Mediterranean Volcanic Province is known as the Central European Volcanic Province (CEVP: Wimmenauer 1974). Variably eroded central volcanic complexes (e.g., Wilson et al. 1995; Rapprich and Holub 2008; Holub et al. 2010; Skála et al. 2014) as 
well as mafic monogenetic volcanic fields (e.g., Mertes and Schmincke 1985; Awdankiewicz 2005, 2013; Rapprich et al. 2007; Cajz et al. 2009; Büchner and Tietz 2012; Tietz and Büchner 2015), often associated with rift zones, are characteristic of the CEVP (Wilson and Downes 1991, 2006).

An excellent example is the Eger Rift in the Bohemian Massif. There, volcanism occurred at several stages from Late Cretaceous to Late Pleistocene; the largest volumes of volcanic rocks were emplaced from volcanic centres in the Eger Rift itself, but numerous volcanic fields were also active adjacent to transverse fault zones, around the rift (Ulrych et al. 2011 and references therein).

Basaltic volcanism in the CEVP, and in the Bohemian Massif in particular, is generally linked with lithospheric extension and melting of upwelling asthenosphere with variable interactions between the melts of asthenospheric and lithospheric origin. However, a number of different petrogenetic models have been proposed to account for the causes of mantle melting, the variable mantle sources involved and their variation in space and time (Lustrino and Wilson 2007 and references therein). The main arguments in this debate include the isotopic characteristics of the least differentiated basaltic rocks. A regional geochemical variation across the CEVP has been recognized, and samples bearing characteristics of the least enriched mantle sources represent volcanoes from the eastern part of CEVP, east of the Eger Rift, from the Lower Silesia region (Blusztajn and Hart 1989; Wilson and Downes 2006).

This paper is focused on monogenetic volcanoes and volcanic rocks of the Strzelin Volcanic Field, located in the eastern part of the Lower Silesia. Based on published papers, revision of field relationships and new petrological and geochemical data, the overview of geology and volcanic evolution of the Strzelin Volcanic Field is given. The new geochemical data, including major and trace elements and the $\mathrm{Nd}, \mathrm{Sr}$ and $\mathrm{Pb}$ isotope ratios, are discussed using geochemical modelling of partial melting and differentiation processes. The significance of the results and conclusions presented in this paper is twofold: 1) they highlight the key role of mantle source heterogeneities in determining the magma compositions and eruptive styles at adjacent monogenetic volcanoes, and 2) they provide further constraints, from the area of most extreme isotopic signatures, on the regional geochemical variation and mantle sources involved in the CEVP.

\section{Methods}

\subsection{Fieldwork, sampling and petrography}

The fieldwork covered all outcrops of alkaline basaltic rocks in the vicinities of the towns Strzelin and Ziębice located south of Wroclaw. Sampling was carried out with reference to volcanic structures and rock types and encompassed various products of successive volcanic phases where present (e.g., lavas, interbedded pyroclastic deposits, cross-cutting dykes, plugs). Overall c. 50 specimens from 18 outcrops were collected. A subset of 30 representative and the freshest specimens was studied in thin sections. Standard petrographic studies using the polarising microscope were followed by chemical analysis of minerals using the electron microprobe. However, the latter results are only qualitatively used here to support the identification of mineral phases, and full results will be published elsewhere. Mineral abbreviations used follow those of Whitney and Evans (2010).

\subsection{Bulk-rock chemistry}

\subsubsection{Major and trace elements}

Twenty-one specimens of the volcanic rocks were selected for whole-rock chemical analysis. After removing weathered fragments, washed and dried samples were crushed and pulverized using tungsten carbide jaw crusher and ring mill at the Institute of Geological Sciences, University of Wrocław. Major- and trace-element bulk-rock analyses were carried out at ACME Labs, Vancouver, Canada. Pulverized rock samples were fused with lithium tetraborate. Following digestion in nitric acid, major and minor elements were analyzed using the inductively coupled plasma emission spectrometry (ICP-ES) and trace elements were determined using the inductively coupled plasma mass spectrometry (ICPMS) (analytical packages 4A, 4B; http://www.acmelab. com). The detection limits were: $0.04 \%$ for $\mathrm{SiO}_{2}, \mathrm{Fe}_{2} \mathrm{O}_{3}$, $\mathrm{K}_{2} \mathrm{O} ; 0.03 \%$ for $\mathrm{Al}_{2} \mathrm{O}_{3} ; 0.1 \%$ for other major elements; 0.5 ppm for Zr, Hf, Ba, Rb, Sr, Nb, La, Ce; 0.4 ppm for Nd; 0.05 ppm for Eu, Gd, Dy, Ho, Er, Tm, Yb; 0.01 ppm for $\mathrm{Tb}$ an $\mathrm{Lu}$; and $0.1 \mathrm{ppm}$ for the other trace elements. Chromium was determined as $\mathrm{Cr}_{2} \mathrm{O}_{3}$ at the detection limit of $0.001 \%$. The geochemical data were handled using the GCDkit software (Janoušek et al. 2006).

\subsection{2. $\mathrm{Sr}-\mathrm{Nd}-\mathrm{Pb}$ isotopes}

Based on major- and trace-element geochemistry, a subset of six samples was selected for $\mathrm{Sr}-\mathrm{Nd}$ and four samples for $\mathrm{Pb}$ isotopic analyses. All leaching and chemical separation procedures were carried out in Class 10,000 clean laboratory of Czech Geological Survey, Prague-Barrandov (CGS) and the mass spectrometric analyses were performed at the CGS (isotopic analyses) and Institute of Geology, Czech Academy of Sciences (concentration analyses). Sample handling in lab was carried out 
in Class 100 laminar flow hoods. All reagents used for $\mathrm{Sr}$ and Nd were in-house double distilled acids (in DST1000, Savillex).

All samples were dissolved in a closed vessel using a 3:7 mixture of concentrated $\mathrm{HNO}_{3}$ and $\mathrm{HF}$ acids on a hotplate at $180^{\circ} \mathrm{C}$ for $\sim 72 \mathrm{~h}$. Afterwards, the dissolved samples were evaporated, $3 \mathrm{ml}$ of $\mathrm{HNO}_{3}$ were added to the residues and dried three times, and finally re-digested in $8 \mathrm{ml}$ of $6 \mathrm{M} \mathrm{HCl}$. Samples for $\mathrm{Pb}$ were dissolved separately from those for $\mathrm{Sr}$ and $\mathrm{Nd}$ isotopes.

The Sr-Nd analytical procedure consists of triple column ion-exchange chemistry (Míková and Denková 2007). Strontium and REE were isolated from the matrix of acid-digested samples by following the techniques of Pin et al. (1994) (PP columns filled with Sr.spec and TRU.spec Eichrom resins for separation of Sr and bulk REE, respectively). The Nd was further separated from the REE fraction on PP columns with Ln.spec Eichrom resin.

Isotopic analyses were performed on a Thermo Finnigan Neptune multi-collector inductively coupled plasma mass spectrometer (MC ICP-MS). The measured Sr isotopic ratios were corrected for mass-dependent instrumental fractionation using exponential law assuming ${ }^{86} \mathrm{Sr} /{ }^{88} \mathrm{Sr}=0.1194$ (Steiger and Jäger 1977). The isobaric interference of $\mathrm{Rb}$ at the mass 87 was corrected using the natural value of ${ }^{87} \mathrm{Rb} /{ }^{85} \mathrm{Rb}=0.3857$ (Steiger and Jäger 1977). Reproducibility of the isotopic determinations is estimated from replicate analyses of the NIST NBS 987 reference material during analytical session, giving an average ${ }^{86} \mathrm{Sr} /{ }^{88} \mathrm{Sr}=0.710338 \pm 10(2 \sigma), \mathrm{n}=8$.

The measured ${ }^{143} \mathrm{Nd} /{ }^{144} \mathrm{Nd}$ ratios were corrected for mass-dependent instrumental fractionation using exponential law to ${ }^{146} \mathrm{Nd} /{ }^{144} \mathrm{Nd}=0.7219$ (Wasserburg et al. 1981). If present, the isobaric interference of Sm at mass 147 was corrected for using the natural isotopic ratio of ${ }^{144} \mathrm{Sm} /{ }^{147} \mathrm{Sm}=0.20648$. During analytical session the replicate analyses of Nd reference material JNdi-1 (Tanaka 2000) gave an average ${ }^{143} \mathrm{Nd} /{ }^{144} \mathrm{Nd}=0.512114 \pm 12(2 \sigma)$, $\mathrm{n}=8$.

In order for the measured $\mathrm{Pb}$ isotopic compositions of basalts to be representative of their respective mantle sources, acid leaching of samples prior to dissolution is an effective tool in removing secondary material (Silva et al. 2009), a key procedure for yielding correct $\mathrm{Pb}$ isotopic compositions (Bouvier et al. 2005). The acidleaching procedure used for $\mathrm{Pb}$ isotopic analyses followed that of A. Stracke (pers. comm.). For dissolution and separation, UpA quality Romil acids were used, all dilutions were made using milliQ water, and all labware was acid-washed prior to use. Approximately 0.1-0.6 g of sample chips (depending on $\mathrm{Pb}$ concentration) were acid-leached with $14 \mathrm{ml}$ of $6 \mathrm{M} \mathrm{HCl}$ in a Savillex beaker in an ultrasonic bath for $60 \mathrm{~min}$. The supernatant (leach- ate solution) was immediately decanted before the fines had time to settle. The samples were then flushed and decanted twice with milliQ water to remove any traces of acid and then acid digested. Subsamples of the digested leached material were measured to determine the amounts of $\mathrm{Pb}$ present after the acid-leaching procedure.

In preparation for $\mathrm{Pb}$ chemistry, the samples were dried and redissolved in $2 \mathrm{M} \mathrm{HCl}$ and loaded onto a pre-cleaned and conditioned $0.2 \mathrm{ml}$ column packed with Sr.Spec resin (50-100 mesh; Triskem, France). The matrix was washed out with $2 \mathrm{M} \mathrm{HCl}$ and $\mathrm{Pb}$ was eluted in $6 \mathrm{M} \mathrm{HCl}$; this procedure results in $\sim 100 \%$ recovery of $\mathrm{Pb}$. After chemical purification, the eluted $\mathrm{Pb}$ fraction was dried, a small quantity of concentrated $\mathrm{HNO}_{3}$ was added to remove any organic material eluted from the resin along with the $\mathrm{Pb}$, and it was dried again. In preparation for isotopic analyses, the dried $\mathrm{Pb}$ fractions were redissolved in $1 \mathrm{ml}$ of $2 \% \mathrm{HNO}_{3}$ with $\mathrm{Tl}$ spike and left overnight to homogenize on a hot plate.

The $\mathrm{Pb}$ isotopic analyses were performed on a Neptune MC-ICP-MS (Thermo Scientific) at the CGS. Instrumental mass fractionation was monitored and corrected online using a NIST SRM $997 \mathrm{Tl}$ standard solution; potential ${ }^{204} \mathrm{Hg}$ isobaric interference on ${ }^{204} \mathrm{~Pb}$ was monitored at mass ${ }^{202} \mathrm{Hg}$ and corrected by assuming natural $\mathrm{Hg}$ isotopic abundances $\left({ }^{202} \mathrm{Hg} /{ }^{204} \mathrm{Hg}=4.35\right)$. Sample analysis followed a sample-standard bracketing protocol in which the SRM-981 Pb standard was run after every sample. The results were then normalized off-line to the SRM 981 certified values and combined statistics for three repeated measurements were calculated. The values for international standard SRM-981 obtained during this study were ${ }^{206} \mathrm{~Pb}^{204} \mathrm{~Pb}=16.9411 \pm 0.0005(2 \sigma),{ }^{207} \mathrm{~Pb}^{204} \mathrm{~Pb}=$ $15.4992 \pm 0.0004(2 \sigma)$ and ${ }^{208} \mathrm{~Pb}^{204} \mathrm{~Pb}=36.7234 \pm 0.0011$ $(2 \sigma)$. The $\mathrm{Pb}$ isotopic ratios were not age-corrected, as the measured concentrations of $\mathrm{Pb}$ were low, and the large error of concentration analysis would propagate into final results.

\section{Regional setting}

The Cenozoic volcanic rocks of the Strzelin Volcanic Field crop out in Lower Silesia, at the NE margin of the Bohemian Massif, c. $100 \mathrm{~km}$ east of the northern tip of the Eger (Ohře) Rift (Fig. 1). The studied area lies between the Sudetic Boundary and the Odra fault zones. These structures belong to a broad zone of prominent NW-trending dislocations including also the Elbe Fault Zone. These dislocations were already active in the Palaeozoic, and some were also reactivated in Meso- and Cenozoic eras. In particular, the Sudetic Boundary Fault shows a strong present-day morphological expression as a scarp up to $300 \mathrm{~m}$ high - separating the uplifted Sude- 


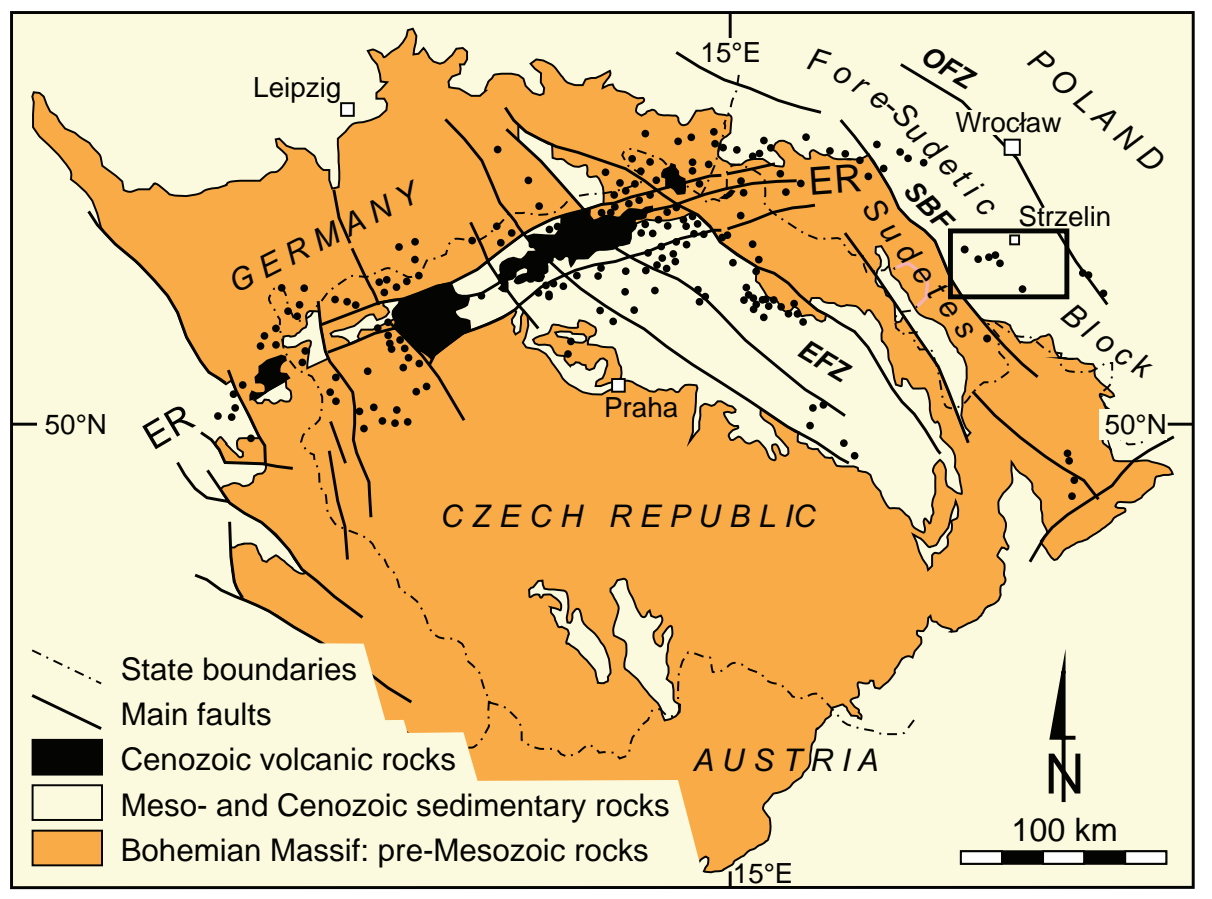

Fig. 1 Geological sketch map of the Bohemian Massif and the Eger Rift (modified from Holub et al. 2010) with the location of the study area - the Strzelin Volcanic Field (black frame). EFZ - Elbe Fault Zone, ER - Eger Rift, OFZ - Odra Fault Zone, SBF - Sudetic Boundary Fault. tes Block in the SW from the downthrown Fore-Sudetic Block, that is bordered further NE by the Odra Fault Zone (e.g., Mazur et al. 2006). The Fore-Sudetic Block is cut by a system of W-E to NW-SE trending horsts and grabens. The Cenozoic volcanic rocks of the Strzelin area occur within the Strzelin (or Strzelin-Ziębice) horst. In Cenozoic, this basement elevation was part of so-called Meta-Carpathian Swell, which was a water divide between the North Sea and the Paratethys in the south (Oberc et al. 1975; Cwojdziński and Jodłowski 1982; Dyjor 1995).

The pre-Cenozoic basement rocks of Lower Silesia are part of the European Variscan Orogenic Belt. In the study area, the crystalline basement comprises several tectonostratigraphic units elongated in the north-south direction and separated by shear zones (Fig. 2), some of which are considered as Variscan terrane boundaries (e.g., Mazur et al. 2006). The main basement lithologies are variable gneisses and crystalline schists intercalated with amphibolites, marbles and quartzites. The Late Proterozoic-Early Palaeozoic protoliths of these crystalline rocks underwent deformation and metamorphism during the Variscan collision in Late Devonian to Carboniferous times (e.g., Oberc-Dziedzic et al. 2005; Schulmann et al. 2014, and references therein). The metamorphic rocks were intruded by granitic plutons of Carboniferous to Permian age (Kozłowski and Wiszniewska 2007; Oberc-Dziedzic et al. 2013a, b, 2015 and references therein). The crystalline basement only partly crops out at the surface, being largely covered by up to a few hundred metres thick sedimentary cover, including Oligocene, Miocene and Pliocene sands and clays, overlain by Pleistocene tills, gravels, sands and loesses (e.g., Sawicki 1967).

The structure and lithology of the lithosphere adjacent to the study area are constrained by drill core data, seismic profiles, heat flow modelling and data from mantle xenoliths (Awdankiewicz 2008; Geissler et al. 2012; Puziewicz et al. 2012, and references therein). According to these studies, the Earth's crust near the study area predominantly consists of various gneisses with minor granites. Amphibolites, locally over $3 \mathrm{~km}$ thick, occur in the near-surface part, and melagabbros are inferred to form the lower crust. The MOHO is located at a depth of $c .31 \mathrm{~km}$ and the lithosphere-asthenosphere boundary at c. $90 \mathrm{~km}$ (Puziewicz et al. 2012) or 100-105 km (Geissler et al. 2012). Recently, Puziewicz et al. (2015) suggested that the transition from spinel to garnet peridotite, corresponding to the base of the lithospheric mantle, occurred at a depth of 50-70 km at the time of Cenozoic volcanism.

\section{Results}

\subsection{Structure, age and subdivision of the volcanic succession}

The Cenozoic volcanic rocks of the Strzelin area occur at nearly twenty small outcrops in $c$. $30 \mathrm{~km}$ long, relatively wide, NW-SE trending belt (Fig. 2). However, some fifty subcrops of basaltic rocks, much more extensive than outcrops, have been recognized adjacent to this belt underneath the Upper Miocene-Quaternary cover 


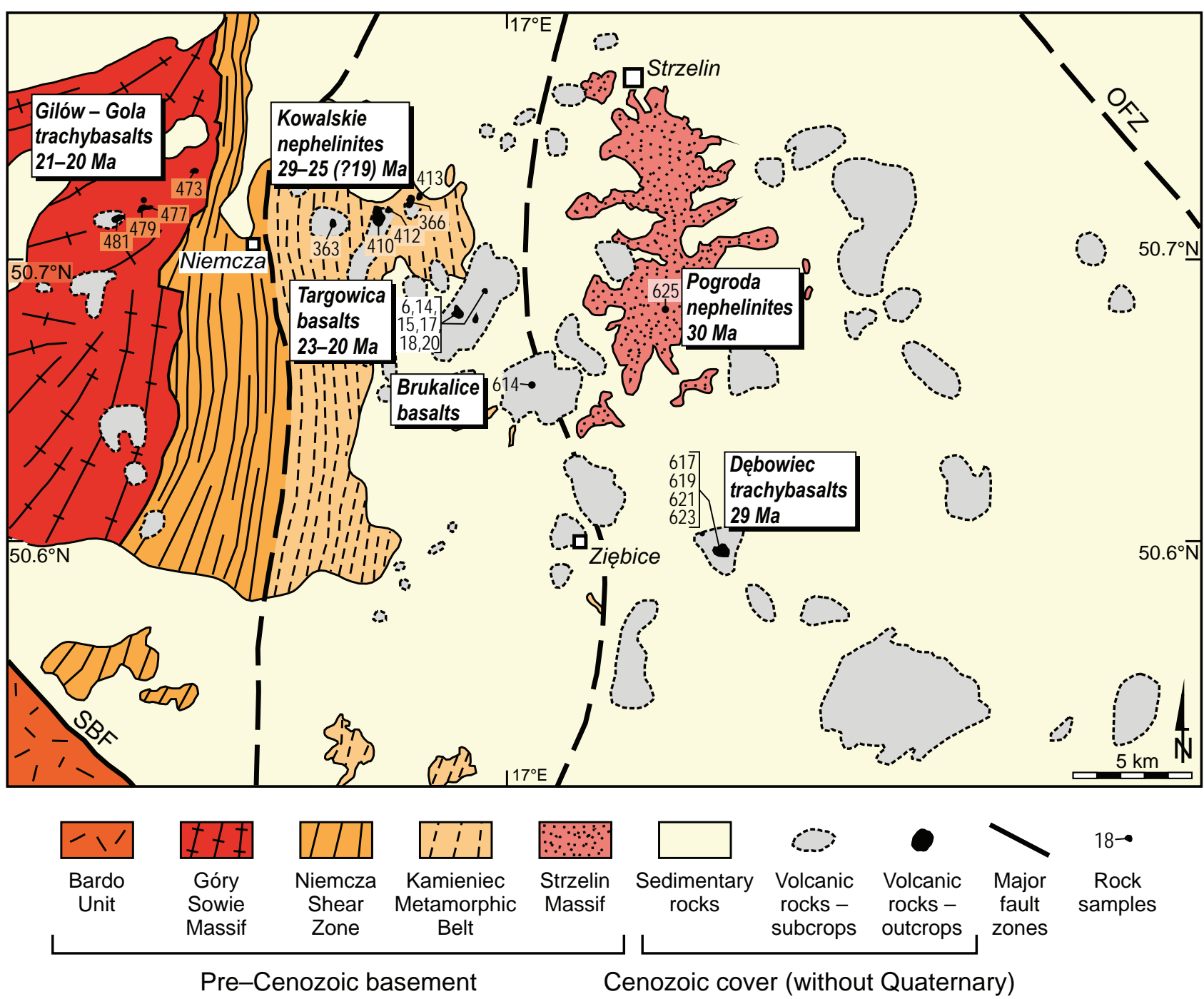

Fig. 2 Geological sketch map of the Strzelin Volcanic Field (modified from Sawicki 1967, Cwojdziński and Jodłowski 1982 and Mazur et al. 2006 ; ages of volcanic rocks from Birkenmajer et al. 2004 and Badura et al. 2005). The volcanic systems studied and the locations of sampling sites are indicated. OFZ - Odra Fault Zone.

using magnetic survey data (Cwojdziński and Jodłowski 1982, and references therein). The "Strzelin-Ziębice basaltic concentration" distinguished by Cwojdziński and Jodłowski (1982) occupies NW-elongated, elliptical area of roughly $50 \times 28 \mathrm{~km}\left(c .1100 \mathrm{~km}^{2}\right)$. Though partly eroded and covered with younger sediments, this "concentration" bears many similarities with modern mediumsized mafic monogenetic volcanic fields (Connor and Conway 2000) in terms of the size, volcanic structures and rock types. Thus, this volcanic region is referred to here as the Strzelin Volcanic Field (SVF).

The published $\mathrm{K}-\mathrm{Ar}$ age determinations of the outcropping volcanic rocks of the SVF (Birkenmajer et al. 2004; Badura et al. 2005) indicate two stages of the Cenozoic volcanism, in Oligocene and Miocene. Volcanic plugs, lava flows and partly eroded volcanic cones have been recognized in the SVF (Birkenmajer et al. 2004; Badura et al. 2005; Awdankiewicz 2005, 2013). Based on the age, composition and spatial distribution, the volcanic succession of the SVF can be subdivided into two main groups and several smaller units (Fig. 2): older, Oligocene (30-28 (25?) Ma) Kowalskie nephelinites, Pogroda nephelinites and Dębowiec trachybasalts, and younger, Early Miocene (c. 23-20 Ma) Targowica basalts, Brukalice basalts and Gilów-Gola trachybasalts.

This classification is tentative and subject to modification, if more occurrences of volcanic rocks in the SVF, especially the subcrops, are drilled and studied in more detail.

\subsection{Volcanic structures, lithologies and samples for this study}

Each of the volcanic rock units distinguished above is specific in terms of volcanic structures and lithologies. The Kowalskie nephelinites comprise six outcrops in 5 

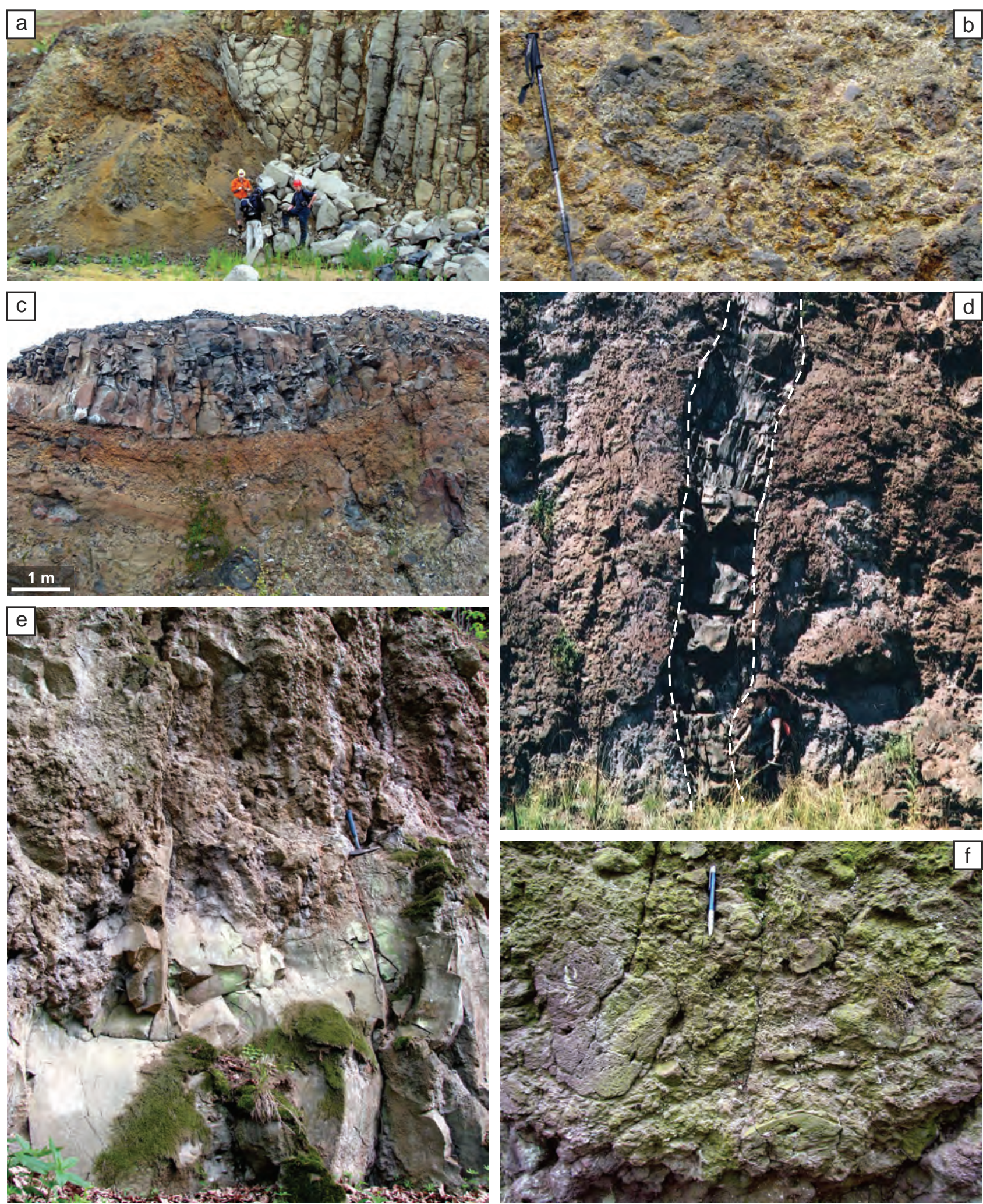

Fig. 3 Lavas, subvolcanic intrusions and volcaniclastic deposits in the Strzelin Volcanic Field. Kowalskie quarry: a - columnar-jointed nephelinite lava piled-up and cooled against a mound(?) of nephelinite breccia rich in yellow clay; $\mathbf{b}$ - close-up of a matrix-supported breccia with scoriaceous lapilli and bombs in a yellow clay-rich matrix. Targowica quarry: c - bedded pyroclastic deposits (scoria-rich lapilli deposits and bomb-rich tuff-agglomerates) overlain by basaltic lava with poorly-developed columnar joints; $\mathbf{d}$ - massive tuff-agglomerates cut by basaltic dyke (outlined). Dębowiec trachybasalts: $\mathbf{e}$ - trachybasaltic lava overlain by scoria and spatter deposits; $\mathbf{f}$ - agglomerate with volcanic bombs of various shapes (e.g., spindle-shaped near the lower edge of photo). 
$\mathrm{km}$ long, ENE-trending zone overlying and locally cutting the crystalline rocks of the Kamieniec Metamorphic Belt (Wójcik 1973). Exposures in abandoned quarries reveal columnar-jointed lavas (Fig. 3a), up to $c$. $20 \mathrm{~m}$ thick, locally in two to three horizons interstratified with breccias and possibly associated with volcanic plug(s) in the western outcrops (Birkenmajer et al. 1970, 2004; August et al. 1995). Some monomictic, clast-supported breccias in the Kowalskie quarry (coordinates: N50.730238 $\mathrm{E} 016.935205^{\circ}$ ) may represent auto-brecciated crust of aalava flows. The other type of breccia is matrix-supported with frequent $\mathrm{cm}$ - to $\mathrm{dm}$-sized scoriaceous bombs and more massive, quenched basaltic clasts in a yellow clayrich matrix (Fig. 3b). This breccia type is tentatively interpreted as a result of rootless explosions with hydroclastic ejecta related to interaction of lava flows with surface water upon emplacement. Explosive eruptions at the Kowalskie volcanic system are also documented by altered lapilli tuffs locally underlying the lavas at Żelowice. Samples 366, 410, 412, 413 of the present study are nephelinite lavas collected from the central and eastern outcrops of the Kowalskie volcanic system, whereas sample 363, a melilite nephelinite, comes from poorly exposed westernmost outcrop, presumably a small plug.

The Pogroda nephelinites form an isolated plug within crystalline rocks of the Strzelin Massif (Wójcik 1965). In a quarry c. $30 \mathrm{~m}$ in diameter (N50.691358 E017.091393 ${ }^{\circ}$ ), largely overgrown, there are small exposures of non-bedded volcanic breccias composed of variably altered, massive to vesicular blocks and finer fragments of nephelinite, with xenoliths of crystalline country rocks. Sample 625 was collected from a more massive and least altered nephelinite block in the talus.

The Targowica basalts comprise a group of three outcrops surrounded by Quaternary deposits (Wójcik 1973), in a centre of more extensive magnetic anomaly interpreted as a subcrop of equivalent basalts (Cwojdziński and Jodłowski 1982 and references therein). The largest, south-westernmost outcrop is extensively quarried at Targowica $\left(\mathrm{N} 50.689297^{\circ}, \mathrm{E} 016.965605^{\circ}\right)$. A partly eroded scoria cone has been recognized there (the Sośnica Hill volcano; Awdankiewicz 2005). The samples used for the present study represent various styles and stages of activity of the Sośnica volcano, including: scoria from the cone-forming, bedded and non-bedded deposits (samples 20 and 15a, respectively, see Fig. 3c and 3d), a lava filling the central crater (sample 17), and subvolcanic intrusions cutting the pyroclastic deposits north-west of the central crater (sample 14 - a dyke, see Fig. 3d, and sample 6 - a plug). In addition, sample 18 has been collected from a smaller basalt outcrop $1.7 \mathrm{~km} \mathrm{NE}$ of the quarry. This sample may represent a lava flow either erupted from the Sośnica volcano, or from another vent in the vicinity.
The Brukalice basalts, few kilometres SE of the Sośnica Volcano, possibly represent a similar, but smaller and poorly exposed volcanic centre. In an abandoned quarry $\left(\mathrm{N} 50.662620^{\circ}, \mathrm{E} 017.015708^{\circ}\right)$ a $10 \mathrm{~m}$ thick aa lava flow overlain by non-bedded to bedded basaltic breccias and agglomerates is exposed. Sample 614 was collected from the coherent, more massive interior facies of the lava flow.

The Dębowiec trachybasalts comprise a group of small outcrops of volcanic and volcaniclastic rocks in an area $c .1 .5 \times 1.5 \mathrm{~km}$, partly covered by Pleistocene to Holocene deposits (Wroński 1970a, b, 1974). Lava flows and abundant near-vent pyroclastic fall deposits (e.g. beds of scoria, spatter, or lapilli-tuffs - see Fig. 3e-f) as well as dykes and plugs can be identified in several old quarries (east of Dębowiec village; N50.59995 ${ }^{\circ}$, E017.12290 ${ }^{\circ}$. These rocks can be tentatively linked to explosive and effusive activity of Strombolian-type cone(s), or fissure vents, with related emplacement of dykes and plugs. Sample 621 was collected from a lava flow underlying pyroclastic deposits, and the other three come from intrusive bodies: a dyke (sample 617) and plugs $(619,623)$.

The Gilów-Gola trachybasalts occur as four small outcrops of volcanogenic rocks aligned in NE-SW trending, c. $4 \mathrm{~km}$ long belt, set within crystalline rocks of the Góry Sowie Block (Cwojdziński and WalczakAugustyniak 1985). The alignment of outcrops may suggest relationship to a NE-trending fault. Most of the trachybasalts are considered as lava flows, and a plug, or a vent fill is inferred in the westernmost outcrop (Birkenmajer 1967; Birkenmajer et al. 1970, 2004). Samples 473, 477 and 479 were collected from lava flows in the eastern and central outcrops, and sample 481 from the lava in the western vent $\left(\mathrm{N} 50.728579^{\circ}, \mathrm{E} 016.753199^{\circ}\right)$.

\subsection{Petrography}

The samples studied comprise three main rock types: nephelinites, basalts and trachybasalts. The main petrographic characteristics are summarized in Tab. 1 and illustrated in Fig. 4. All samples are porphyritic, with up to 5-10 vol. \% phenocrysts in the nephelinites and up to 3-5 vol. \% in the basalts and trachybasalts. The phenocrysts are less than $2 \mathrm{~mm}$ in size in the nephelinites and usually smaller than $1-0.5 \mathrm{~mm}$ in the other rock types. The phenocrysts are formed by olivine and diopside, which occur in variable proportions. Typically, olivine is more abundant (nephelinites and Dębowiec trachybasalts) or even strongly predominant (Targowica and Brukalice basalts); more rarely, diopside is the prevailing phenocryst phase (Gilów-Gola trachybasalts). The microcrystalline groundmass consists of mainly subhedral to anhedral crystals of diopside, opaque minerals and nepheline (in the nephelinites); diopside, plagioclase and opaque minerals (in 

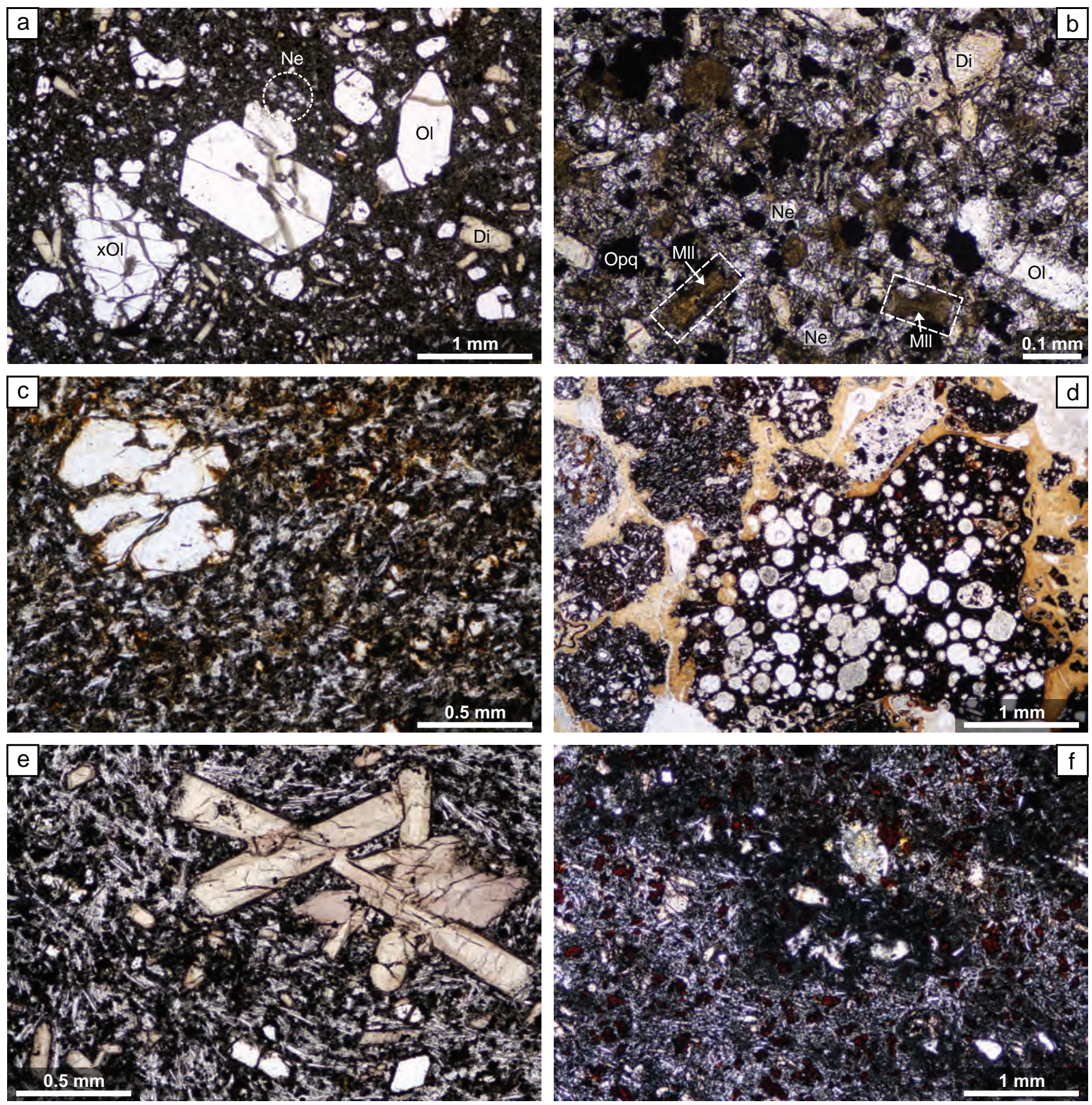

Fig. 4 Photomicrographs (plane-polarized light) of representative samples of volcanic rocks. Location of samples is given in Fig. 2. Kowalskie nephelinites: a - euhedral to subhedral olivine phenocrysts and anhedral xenocrysts, together with diopside microphenocrysts, set in microcrystalline groundmass of diopside, opaques and nepheline (sample 366, lava flow); $\mathbf{b}$ - close-up of the groundmass of the melilite nephelinite composed of nepheline, melilite (partly altered: brownish colour in transmitted light is due to replacement by clay minerals with Fe-hydroxides), opaques, diopside and minor olivine (sample 366, lava in plug). Targowica basalts: c - embayed phenocryst of olivine in microcrystalline groundmass of diopside, plagioclase and opaques (sample 20, lava flow); d - pyroclastic fragments in a lapilli tuff (location the same as sample 20). The fragments shown, of coarse ash and fine lapilli fraction, represent small clasts of scoria characterized by variable vesicularity and crystallinity. The clasts are cemented with brownish clay mineral (smectite). Gilów trachybasalt: e - Glomerocryst of diopside and rare microphenocrysts of olivine are set in a groundmass of plagioclase laths (with associated anhedral alkali feldspar), subhedral diopside and opaques. Variable shades of light-brown in diopsides are due to sector zonation (sample 473, lava flow). Dębowiec trachybasalt: $\mathbf{f}$ - petrographically heterogeneous sample that shows 1-5 mm wide, lighter and darker patches and bands which differ in the degree of crystallinity and microlith size. The darker domains contain less abundant and smaller plagioclase microliths, but more abundant opaque-rich interstitial glass. The domains may represent relics of clastogenic textures (sample 621, lava flow).

$\mathrm{Di}$ - diopside; Mll - melilite; $\mathrm{Ne}$ - nepheline; Ol - olivine; xOl - xenocryst of olivine; Opq - opaque minerals (mostly titanomagnetite and/or ilmenite) 
Tab. 1 The main petrographic characteristics of volcanic rocks of the Strzelin Volcanic Field

\begin{tabular}{|c|c|c|c|c|c|c|c|c|}
\hline \multirow[b]{2}{*}{ Volcanic centre (samples) } & \multirow[b]{2}{*}{ Volcanic structures } & \multicolumn{4}{|c|}{ Selected petrographic features of coherent facies rocks* } & \multicolumn{3}{|c|}{ Enclaves, xenocrysts*** } \\
\hline & & $\begin{array}{c}\text { phenocryst } \\
\text { content (vol. \%) }\end{array}$ & $\begin{array}{l}\text { phenocryst } \\
\text { size }(\mathrm{mm})\end{array}$ & $\begin{array}{c}\text { phenocryst } \\
\text { assemblage** }\end{array}$ & $\begin{array}{l}\text { groundmass } \\
\text { minerals } * *\end{array}$ & $\begin{array}{l}\text { ultra- } \\
\text { mafic }\end{array}$ & felsic & other \\
\hline $\begin{array}{l}\text { Kowalskie nephelinites } \\
(363,366,410412,413)\end{array}$ & lava flows, plugs(?) & 5-10 & $<2$ & Ol, Di & $\begin{array}{l}\mathrm{Di}, \mathrm{Ne}, \mathrm{Opq}(+\mathrm{Mll} \\
\text { in sample 363) }\end{array}$ & $\mathrm{y}$ & $\mathrm{n}$ & $\mathrm{y}$ \\
\hline $\begin{array}{l}\text { Pogroda nephelinites } \\
(625)\end{array}$ & plug & 5 & $<2$ & Ol, Di & Di, Ne, Opq & $\mathrm{n}$ & $\mathrm{y}$ & $\mathrm{n}$ \\
\hline $\begin{array}{l}\text { Targowica basalts } \\
(6,14,17,18)^{* * * *}\end{array}$ & $\begin{array}{l}\text { partly eroded scoria cone } \\
\text { with dykes and lava flows }\end{array}$ & $3-5$ & $<1$ & $\mathrm{Ol}>\mathrm{Di}$ & Di, Pl, Opq & $\mathrm{y}$ & $\mathrm{y}$ & $\mathrm{n}$ \\
\hline Brukalice basalts (614) & $\begin{array}{l}\text { partly eroded scoria cone } \\
\text { with lava flows(?) }\end{array}$ & $3-5$ & $<1.5$ & $\mathrm{Ol}$ & $\mathrm{Di}, \mathrm{Pl}, \mathrm{Opq}$ & $\mathrm{n}$ & $\mathrm{n}$ & $\mathrm{n}$ \\
\hline $\begin{array}{l}\text { Gola-Gilów trachybasalts } \\
(473,477,479,481)\end{array}$ & plugs & $3-5$ & $<1$ & $\mathrm{Di}>\mathrm{Ol}$ & Pl, Di, Afs, Opq & $\mathrm{y}$ & $\mathrm{y}$ & $\mathrm{n}$ \\
\hline $\begin{array}{l}\text { Dębowiec trachybasalts } \\
(617,619,621,623)\end{array}$ & $\begin{array}{c}\text { relics of eroded scoria and } \\
\text { spatter cones, lava flows, } \\
\text { plugs }\end{array}$ & $3-5$ & $<1$ & Ol, Di & Pl, Di, Afs, Opq & $\mathrm{n}$ & $n$ & $\mathrm{y}$ \\
\hline
\end{tabular}

* Features common to all samples: porphyritic, massive texture, microcrystalline groundmass; rarely directional, vesicular or relic clastogenic textures

** Minerals: Afs - alkali feldspar, Di - diopside, Mll - melilite, Ne - nepheline, Opq - opaques, Pl - plagioclase

*** Inclusions: $\mathrm{y}$ - present, $\mathrm{n}$ - not present

**** Samples 15 and 18, not included in these characteristics, are partly altered scoria clasts. Compared to the coherent rocks they are hypocrystalline, with abundant post-magmatic phases (mainly clay minerals and hematite)

the basalts) and diopside, plagioclase, alkali feldspar and opaques (in the trachybasalts). Minor amounts of interstitial glass occur in some specimens. Apatite is a common accessory phase and melilite, variably replaced by clay minerals and possibly forming also pseudomorphs after perovskite(?), appears in the groundmass of the melilite nephelinite. Groundmass textures are typically massive, although small vesicles were observed in some samples. Preferred orientation of elongated minerals and flattened vesicles are rare. Some specimens are partly heterogeneous and contain indistinct domains, up to several millimetres across, which differ in phenocryst content and size, crystallinity (amount and size of microcrysts versus glass in groundmass) or vesicle content. These domains may represent remnants of clastogenic textures, e.g., relics of spatter from Hawaiian-type eruptions, incompletely homogenized within lava flows, or autoclastic breccia re-annealed by the lava.

The phenocryst assemblages of the rocks studied are partly heterogeneous in terms of zoning and other textural features. Olivine and diopside phenocrysts vary in habit from euhedral to subhedral/anhedral. Olivine frequently displays embayments and it is normally zoned. Diopside phenocrysts usually show sector-type zonation, and some feature also distinctive greenish cores and concentric, oscillatory zonation. Glomerocrysts of radially-arranged diopside phenocrysts are found in most samples.

Small (millimetre-size) enclaves/xenocrysts can be identified in most specimens. These are variable in modal composition and texture and can be grouped into: (1) ultramafic (peridotite) xenoliths and mafic xenocrysts, (2) felsic, quartz-rich xenoliths and quartz xenocrysts, (3) other types of enclaves. The peridotite xenoliths are dominated by olivine, with minor pyroxenes \pm accessory spinel. Some larger olivine and clinopyroxene crystals in the volcanic rocks were presumably derived from disintegration of such peridotite xenoliths. These ultramafic xenoliths and mafic xenocrysts can be identified in $c$. one third of the samples studied. Felsic, quartz-rich xenoliths (cataclasite, quartzite and tonalite), as well as quartz xenocrysts, were noted in $c$. one fifth of specimens. These xenoliths and xenocrysts are surrounded by reaction coronas rich in clinopyroxene; more rarely they show also discontinuous glassy envelopes. In addition, some samples contain plagioclase macrocrysts, poikilitic clinopyroxene macrocrysts, or olivine-clinopyroxene aggregates; all these may represent various types of xenocrystic to cognate materials. Individual volcanic centres of the study area tend to show specific assemblages of enclaves and xenocrysts (Tab. 1).

Sampling of altered or weathered specimens was generally avoided. However, most specimens collected do contain some amounts of post-magmatic phases. Partial to strong replacement of olivine by iddingsite is the most typical. In addition, there are clay minerals (smectite?), calcite or minor zeolites that replace interstitial glass and fill vesicles. The post-magmatic minerals are especially frequent in basaltic and trachybasaltic pyroclastic rocks at Targowica and Dębowiec, which usually show a pronounced to complete replacement of the primary igneous phases.

\subsection{Major- and trace-element geochemistry}

Chemical analyses of the volcanic rocks studied are shown in Tab. 2. The mafic volcanic rocks of the SVF represent the alkaline sodic series and are poor in silica. The samples from Kowalskie and Pogroda plot in the basanite/tephrite field of the TAS diagram (Le Maitre et al. 2002; Fig. 5a). However, the distinction between foi- 
Tab. 2 Whole-rock chemical analyses of the volcanic rocks

\begin{tabular}{|c|c|c|c|c|c|c|c|c|c|c|c|c|}
\hline Sample & 363 & 366 & 410 & 412 & 413 & 625 & 14 & $15 \mathrm{~A}$ & 17 & 18 & 20 & 6 \\
\hline Rock unit & $\mathrm{KN}$ & $\mathrm{KN}$ & $\mathrm{KN}$ & KN & $\mathrm{KN}$ & PN & TB & TB & $\mathrm{TB}$ & TB & TB & TB \\
\hline $\mathrm{SiO}_{2}$ & 39.99 & 40.92 & 40.00 & 40.81 & 40.64 & 43.35 & 43.79 & 44.20 & 45.31 & 45.85 & 43.45 & 45.06 \\
\hline $\mathrm{TiO}_{2}$ & 2.42 & 2.28 & 2.28 & 2.27 & 2.29 & 2.56 & 3.20 & 3.52 & 2.66 & 3.37 & 3.32 & 2.87 \\
\hline $\mathrm{Al}_{2} \mathrm{O}_{3}$ & 10.95 & 11.05 & 11.55 & 11.63 & 11.48 & 11.93 & 13.28 & 14.82 & 13.49 & 14.18 & 13.94 & 13.52 \\
\hline $\mathrm{Fe}_{2} \mathrm{O}_{3}$ * & 13.14 & 12.57 & 12.79 & 12.61 & 12.49 & 12.14 & 12.84 & 14.66 & 12.31 & 13.29 & 13.74 & 12.69 \\
\hline $\mathrm{MnO}$ & 0.21 & 0.20 & 0.21 & 0.20 & 0.21 & 0.18 & 0.17 & 0.13 & 0.17 & 0.16 & 0.13 & 0.17 \\
\hline $\mathrm{MgO}$ & 12.44 & 12.70 & 12.77 & 12.90 & 12.58 & 10.81 & 8.74 & 3.23 & 8.88 & 6.87 & 5.57 & 8.46 \\
\hline $\mathrm{CaO}$ & 12.53 & 13.05 & 12.59 & 12.42 & 12.64 & 11.62 & 10.18 & 6.33 & 10.23 & 9.32 & 6.30 & 10.26 \\
\hline $\mathrm{Na}_{2} \mathrm{O}$ & 3.79 & 2.68 & 3.39 & 3.47 & 2.74 & 3.15 & 3.59 & 2.31 & 3.15 & 3.97 & 1.99 & 3.82 \\
\hline $\mathrm{K}_{2} \mathrm{O}$ & 1.30 & 0.76 & 1.01 & 0.76 & 0.61 & 1.36 & 1.23 & 1.27 & 1.09 & 1.23 & 1.25 & 0.85 \\
\hline $\mathrm{P}_{2} \mathrm{O}_{5}$ & 1.37 & 1.09 & 1.15 & 0.98 & 0.99 & 0.98 & 0.70 & 0.75 & 0.58 & 0.66 & 0.72 & 0.67 \\
\hline LOI & 1.40 & 2.20 & 1.90 & 1.60 & 3.00 & 1.60 & 0.86 & 7.77 & 0.80 & 0.67 & 8.47 & 0.49 \\
\hline Total & 99.54 & 99.50 & 99.64 & 99.65 & 99.67 & 99.68 & 98.57 & 98.99 & 98.67 & 99.57 & 98.89 & 98.86 \\
\hline Mg\# & 0.65 & 0.67 & 0.66 & 0.67 & 0.67 & 0.64 & 0.57 & 0.30 & 0.59 & 0.51 & 0.45 & 0.57 \\
\hline $\mathrm{C}$ & 0.02 & 0.02 & 0.02 & 0.07 & 0.12 & 0.02 & nd & nd & nd & nd & nd & nd \\
\hline S & 0.06 & 0.03 & 0.01 & 0.03 & 0.03 & 0.02 & 0.01 & 0.01 & 0.01 & 0.01 & 0.01 & 0.01 \\
\hline $\mathrm{Cr}$ & 301 & 417 & 376 & 424 & 431 & 298 & 213 & 277 & 252 & 179 & 252 & 203 \\
\hline $\mathrm{Ni}$ & 206 & 248 & 225 & 224 & 229 & 167 & 141 & 150 & 142 & 124 & 139 & 157 \\
\hline $\mathrm{V}$ & 246 & 245 & 250 & 250 & 258 & 218 & 238 & 246 & 226 & 228 & 175 & 254 \\
\hline Sc & 19 & 22 & 23 & 24 & 24 & 21 & 18.6 & 20.6 & 20.8 & 16 & 20.5 & 19.3 \\
\hline $\mathrm{Ba}$ & 506 & 634 & 815 & 704 & 705 & 794 & 527 & 549 & 490 & 531 & 577 & 491 \\
\hline $\mathrm{Rb}$ & 36.0 & 21.1 & 41.0 & 38.3 & 24.5 & 37.4 & 31.9 & 21.0 & 28.9 & 27.6 & 31.3 & 23.6 \\
\hline $\mathrm{Sr}$ & 1054 & 1206 & 1243 & 1087 & 1068 & 1324 & 731 & 785 & 658 & 699 & 693 & 643 \\
\hline Cs & 0.5 & 0.5 & 1.3 & 0.4 & 0.7 & 1.5 & 0.5 & bdl & bdl & 0.8 & bdl & bdl \\
\hline Th & 11 & 7.9 & 12.3 & 11.6 & 10 & 9.9 & 5.2 & 5.1 & 4.6 & 4.3 & 5.1 & 5.1 \\
\hline $\mathrm{U}$ & 3.3 & 2.6 & 2.9 & 2.9 & 2.6 & 2.6 & 1.5 & 1.5 & 1.3 & 1.3 & 1.4 & 1.4 \\
\hline $\mathrm{Zr}$ & 299 & 252 & 262 & 246 & 255 & 268 & 249 & 229 & 200 & 270 & 255 & 205 \\
\hline $\mathrm{Hf}$ & 7.6 & 6.3 & 5.9 & 6.5 & 6.4 & 6.4 & 6.4 & 6.5 & 5.2 & 7.3 & 6.7 & 5.5 \\
\hline $\mathrm{Nb}$ & 116.6 & 91.2 & 103.0 & 92.6 & 94.7 & 93.2 & 68.1 & 64.9 & 61.5 & 60.4 & 71.5 & 56.4 \\
\hline Та & 6.3 & 4.9 & 5.5 & 5.2 & 5.2 & 4.8 & 3.8 & 4.0 & 3.0 & 3.5 & 3.8 & 3.3 \\
\hline $\mathrm{Y}$ & 36.4 & 32.5 & 35.0 & 32.9 & 33.4 & 31.5 & 28.8 & 28.9 & 27.3 & 28.9 & 34.5 & 27.3 \\
\hline $\mathrm{La}$ & 91.0 & 73.0 & 85.0 & 78.9 & 79.4 & 71.8 & 38.1 & 38.1 & 32.9 & 33.1 & 38.8 & 36.9 \\
\hline $\mathrm{Ce}$ & 188.6 & 148.0 & 167.4 & 151.3 & 156.3 & 162.7 & 72.0 & 70.8 & 61.2 & 66.5 & 68.3 & 68.9 \\
\hline $\operatorname{Pr}$ & 20.0 & 16.2 & 18.0 & 16.3 & 17.1 & 16.7 & 8.6 & 8.7 & 7.2 & 8.4 & 9.1 & 8.0 \\
\hline $\mathrm{Nd}$ & 78.6 & 64.2 & 73.6 & 67.7 & 69.1 & 68.3 & 38.5 & 38.5 & 31.5 & 39.3 & 41.3 & 35.0 \\
\hline Sm & 13.8 & 11.8 & 12.9 & 12.0 & 12.5 & 11.6 & 9.4 & 9.6 & 7.6 & 10.2 & 10.2 & 8.4 \\
\hline $\mathrm{Eu}$ & 4.46 & 3.84 & 3.89 & 3.53 & 3.76 & 3.53 & 3.08 & 3.27 & 2.65 & 3.46 & 3.53 & 2.83 \\
\hline Gd & 10.44 & 9.28 & 9.51 & 8.91 & 9.25 & 8.89 & 9.00 & 9.27 & 7.77 & 10.05 & 10.31 & 8.40 \\
\hline $\mathrm{Tb}$ & 1.50 & 1.34 & 1.49 & 1.39 & 1.46 & 1.37 & 1.40 & 1.43 & 1.25 & 1.54 & 1.62 & 1.29 \\
\hline Dy & 7.39 & 6.37 & 7.30 & 6.50 & 6.79 & 6.66 & 6.72 & 6.92 & 6.16 & 7.09 & 7.74 & 6.39 \\
\hline Но & 1.25 & 1.14 & 1.20 & 1.11 & 1.14 & 1.06 & 1.08 & 1.14 & 1.05 & 1.12 & 1.29 & 1.06 \\
\hline $\mathrm{Er}$ & 2.79 & 2.60 & 2.87 & 2.65 & 2.73 & 2.78 & 2.82 & 2.91 & 2.71 & 2.71 & 3.30 & 2.88 \\
\hline $\mathrm{Tm}$ & 0.36 & 0.33 & 0.37 & 0.34 & 0.35 & 0.37 & 0.33 & 0.34 & 0.35 & 0.31 & 0.39 & 0.36 \\
\hline $\mathrm{Yb}$ & 2.03 & 2.09 & 2.27 & 2.17 & 2.06 & 2.08 & 1.85 & 1.89 & 1.93 & 1.69 & 2.13 & 1.99 \\
\hline $\mathrm{Lu}$ & 0.29 & 0.27 & 0.31 & 0.29 & 0.28 & 0.31 & 0.24 & 0.23 & 0.26 & 0.21 & 0.28 & 0.27 \\
\hline Co & 99.8 & 85.1 & 96.2 & 87.4 & 89.1 & 121.7 & 3.3 & 5.7 & 2.5 & 2.2 & bdl & 2.7 \\
\hline Mo & 3.5 & 3.3 & 2.6 & 4.0 & 3.1 & 2.8 & 81.0 & 46.0 & 78.0 & 65.0 & 47.0 & 82.0 \\
\hline $\mathrm{Cu}$ & 58.9 & 61.9 & 59.1 & 57.7 & 58.6 & 51.2 & 42.5 & 43.2 & 33.1 & 30.3 & 40.4 & 35.7 \\
\hline Zn & 108 & 98 & 100 & 97 & 103 & 76 & 125 & 149 & 114 & 137 & 135 & 116 \\
\hline $\mathrm{Pb}$ & 4.8 & 4.0 & 5.0 & 3.5 & 3.3 & 2.7 & bdl & 5.1 & bdl & bdl & bdl & bdl \\
\hline $\mathrm{Ga}$ & 21.4 & 19.8 & 20.8 & 20.1 & 20.5 & 19.3 & 28.1 & 27.1 & 26.1 & 30.9 & 28.0 & 25.6 \\
\hline
\end{tabular}

Rock units: KN - Kowalskie nephelinites, PN - Pogroda nephelinites, TB - Targowica basalts, BB - Brukalice basalts, DT - Dębowiec trachybasalts, GGT - Gilów-Gola trachybasalts

Major and minor elements ( $\mathrm{SiO}_{2}$ to $\left.\mathrm{S}\right)$ in wt. \%; trace elements ( $\mathrm{Cr}$ to $\left.\mathrm{Ga}\right)$ in ppm

$\mathrm{Fe}_{2} \mathrm{O}_{3}{ }^{*}$ - total $\mathrm{Fe}$ as $\mathrm{Fe}_{2} \mathrm{O}_{3}$

$\mathrm{Mg} \#=\mathrm{MgO} /(\mathrm{MgO}+\mathrm{FeOt})$ in molar proportions with total $\mathrm{Fe}$ as $\mathrm{FeO}(\mathrm{FeOt})$

nd - not determined; bdl - below detection limit 
Tab. 2 Continued

\begin{tabular}{|c|c|c|c|c|c|c|c|c|c|}
\hline Sample & 614 & 617 & 619 & 621 & 623 & 473 & 477 & 479 & 481 \\
\hline Rock unit & $\mathrm{BB}$ & DT & DT & DT & DT & GGT & GGT & GGT & GGT \\
\hline $\mathrm{SiO}_{2}$ & 41.73 & 44.64 & 44.92 & 44.95 & 45.50 & 44.92 & 45.64 & 45.21 & 44.95 \\
\hline $\mathrm{TiO}_{2}$ & 3.08 & 3.38 & 3.55 & 3.53 & 3.24 & 2.99 & 3.12 & 3.02 & 2.87 \\
\hline $\mathrm{Al}_{2} \mathrm{O}_{3}$ & 13.28 & 13.93 & 14.42 & 14.26 & 14.04 & 14.28 & 13.99 & 14.00 & 13.77 \\
\hline $\mathrm{Fe}_{2} \mathrm{O}_{3} *$ & 13.22 & 13.40 & 13.58 & 13.55 & 12.93 & 11.96 & 12.55 & 12.57 & 12.21 \\
\hline $\mathrm{MnO}$ & 0.21 & 0.17 & 0.17 & 0.17 & 0.16 & 0.16 & 0.17 & 0.17 & 0.17 \\
\hline $\mathrm{MgO}$ & 6.76 & 6.15 & 5.67 & 5.42 & 5.66 & 8.85 & 8.80 & 8.97 & 8.81 \\
\hline $\mathrm{CaO}$ & 11.30 & 9.66 & 9.53 & 9.37 & 9.76 & 9.47 & 9.12 & 9.23 & 9.64 \\
\hline $\mathrm{Na}_{2} \mathrm{O}$ & 2.45 & 3.99 & 4.14 & 3.98 & 4.35 & 3.41 & 4.00 & 3.75 & 3.53 \\
\hline $\mathrm{K}_{2} \mathrm{O}$ & 0.47 & 1.10 & 1.23 & 1.19 & 1.06 & 1.45 & 1.48 & 1.44 & 1.41 \\
\hline $\mathrm{P}_{2} \mathrm{O}_{5}$ & 0.72 & 0.84 & 0.85 & 0.83 & 0.84 & 0.67 & 0.69 & 0.70 & 0.69 \\
\hline LOI & 6.40 & 2.50 & 1.70 & 2.50 & 2.20 & 2.00 & 0.60 & 1.10 & 2.10 \\
\hline Total & 99.62 & 99.76 & 99.76 & 99.75 & 99.74 & 100.16 & 100.16 & 100.16 & 100.15 \\
\hline Mg\# & 0.50 & 0.48 & 0.45 & 0.44 & 0.46 & 0.59 & 0.58 & 0.59 & 0.59 \\
\hline C & 0.26 & 0.02 & 0.01 & 0.02 & 0.02 & 0.03 & 0.02 & 0.02 & 0.03 \\
\hline$S$ & nd & nd & nd & nd & nd & 0.01 & 0.01 & 0.01 & 0.01 \\
\hline $\mathrm{Cr}$ & 240 & 194 & 156 & 136 & 201 & 185 & 192 & 198 & 185 \\
\hline $\mathrm{Ni}$ & 102 & 92 & 92 & 89 & 106 & 106 & 122 & 118 & 112 \\
\hline $\mathrm{V}$ & 277 & 216 & 225 & 226 & 200 & 205 & 201 & 206 & 197 \\
\hline Sc & 21 & 20 & 19 & 19 & 19 & 18 & 18 & 18 & 18 \\
\hline $\mathrm{Ba}$ & 2123 & 557 & 527 & 579 & 540 & 527 & 517 & 538 & 538 \\
\hline $\mathrm{Rb}$ & 9.8 & 48.4 & 35.9 & 31.7 & 47.1 & 43.1 & 40.1 & 39.7 & 35.9 \\
\hline Sr & 695 & 854 & 821 & 824 & 852 & 898 & 802 & 812 & 789 \\
\hline Cs & 0.5 & 1.4 & 1.2 & 2.4 & 0.7 & 0.5 & 0.6 & 0.7 & 0.6 \\
\hline Th & 4.0 & 6.4 & 5.0 & 6.2 & 6.1 & 5.3 & 5.0 & 5.4 & 5.7 \\
\hline $\mathrm{U}$ & 1.4 & 1.9 & 1.7 & 1.6 & 1.9 & 1.9 & 1.9 & 2 & 1.8 \\
\hline $\mathrm{Zr}$ & 236 & 455 & 467 & 463 & 435 & 335 & 340 & 340 & 324 \\
\hline Hf & 5.9 & 11.5 & 11.4 & 11.6 & 11.1 & 8.8 & 8.4 & 9.9 & 8.3 \\
\hline $\mathrm{Nb}$ & 57.7 & 85.2 & 83.6 & 84.0 & 82.9 & 63.7 & 60.0 & 60.1 & 63.0 \\
\hline Тa & 3.0 & 5.7 & 5.7 & 5.9 & 5.4 & 4.0 & 3.9 & 4.0 & 4.0 \\
\hline $\mathrm{Y}$ & 32.2 & 43.5 & 43.0 & 41.9 & 40.5 & 39.6 & 37.9 & 38.1 & 37.6 \\
\hline $\mathrm{La}$ & 30.6 & 38.8 & 35.9 & 35.1 & 39.4 & 42.8 & 41.3 & 41.3 & 42.6 \\
\hline $\mathrm{Ce}$ & 70.0 & 93.9 & 89.5 & 88.5 & 95.5 & 89.6 & 89.3 & 86.4 & 85.8 \\
\hline $\operatorname{Pr}$ & 8.3 & 11.6 & 10.9 & 11.1 & 11.4 & 10.5 & 10.5 & 10.6 & 10.2 \\
\hline $\mathrm{Nd}$ & 39.3 & 56.5 & 51.5 & 51.5 & 53.0 & 44.5 & 45.4 & 46.6 & 40.8 \\
\hline Sm & 8.5 & 12.6 & 12.5 & 11.9 & 12.0 & 11.3 & 11.5 & 11.7 & 10.5 \\
\hline $\mathrm{Eu}$ & 2.81 & 4.03 & 4.01 & 3.99 & 3.88 & 3.68 & 3.52 & 3.79 & 3.40 \\
\hline Gd & 8.64 & 12.18 & 11.68 & 11.66 & 10.79 & 9.48 & 10.39 & 10.55 & 9.43 \\
\hline $\mathrm{Tb}$ & 1.35 & 1.82 & 1.90 & 1.84 & 1.79 & 1.56 & 1.64 & 1.52 & 1.47 \\
\hline Dy & 6.73 & 9.21 & 9.31 & 8.88 & 8.45 & 8.20 & 8.09 & 7.85 & 7.67 \\
\hline Но & 1.05 & 1.47 & 1.38 & 1.36 & 1.32 & 1.34 & 1.39 & 1.38 & 1.31 \\
\hline Er & 2.85 & 3.72 & 3.63 & 3.46 & 3.46 & 3.00 & 2.87 & 3.11 & 3.15 \\
\hline $\mathrm{Tm}$ & 0.32 & 0.49 & 0.43 & 0.43 & 0.43 & 0.41 & 0.37 & 0.36 & 0.41 \\
\hline $\mathrm{Yb}$ & 1.99 & 2.60 & 2.39 & 2.30 & 2.32 & 2.28 & 2.30 & 2.26 & 2.23 \\
\hline $\mathrm{Lu}$ & 0.26 & 0.36 & 0.32 & 0.32 & 0.32 & 0.30 & 0.30 & 0.29 & 0.31 \\
\hline Co & 77.3 & 128.9 & 126.8 & 116.0 & 109.8 & 112.2 & 102.6 & 98.0 & 84.6 \\
\hline Mo & 0.6 & 2.4 & 2.6 & 2.3 & 3.0 & 2.3 & 2.9 & 2.5 & 2.7 \\
\hline $\mathrm{Cu}$ & 28.5 & 27.6 & 35.1 & 24.5 & 31.6 & 34.5 & 36.7 & 37.2 & 35.9 \\
\hline $\mathrm{Zn}$ & 56 & 113 & 135 & 144 & 121 & 111 & 127 & 121 & 120 \\
\hline $\mathrm{Pb}$ & 0.3 & 0.6 & 0.4 & 0.4 & 0.9 & 1.0 & 0.5 & 0.6 & 0.7 \\
\hline Ga & 22.8 & 27.9 & 29.0 & 29.1 & 26.4 & 27.1 & 26.7 & 27.3 & 26.6 \\
\hline
\end{tabular}

tive nepheline, albite and olivine (Electronic supplementary Table 1), two of the samples would be classified as melanephelinites and four as basanites (Le Bas 1989). However, none of these samples contains modal plagioclase, and with the exception of Pogroda nephelinite, nepheline is the only felsic mineral identified in thin sections. Therefore, the ultrabasic samples discussed here are classified as nephelinites. In addition, the Pogroda sample contains minor alkali feldspar and shows higher silica contents, which can be linked with abundant quartz xenocrysts or some alteration in the specimen analyzed.

The samples from Gilów and Dębowiec plot in a tighter cluster in the trachybasalt field, and those from Targowica and Brukalice in the basalt field (with one lava sample from Targowica in the trachybasalt field) (Fig. 5a). The TAS classification of these samples is consistent with their modal mineralogy: plagioclase is the strongly predominant felsic mineral in the Targowica and Brukalice samples, whereas the Gilów and Dębowiec samples contain plagioclase and subordinate alkali feldspar. In addition, the lava sample from Brukalice and scoria samples from Targowica are shifted towards lower alkali contents, mainly due to depletion in $\mathrm{Na}$, which can be linked to weathering or post-magmatic alteration, documented also by high LOI (up to 9 wt. \%). The $\mathrm{Zr} /$ Ti vs. Nb/Y diagram (Fig. 5b), based on the ratios of relatively immobile trace-elements, con- dites (e.g. nephelinites) and basanites/tephrites using the TAS plot is unsatisfactory and additional criteria, such as the CIPW norm or modal composition, must be applied (Le Maitre et al. 2002). Based on the contents of norma- firms affinities of the altered samples from Brukalice and Targowica to the unaltered Targowica basalts, and of the sample from Pogroda to the Kowlaskie nephelinites. This diagram displays also well the subdivision of studied 

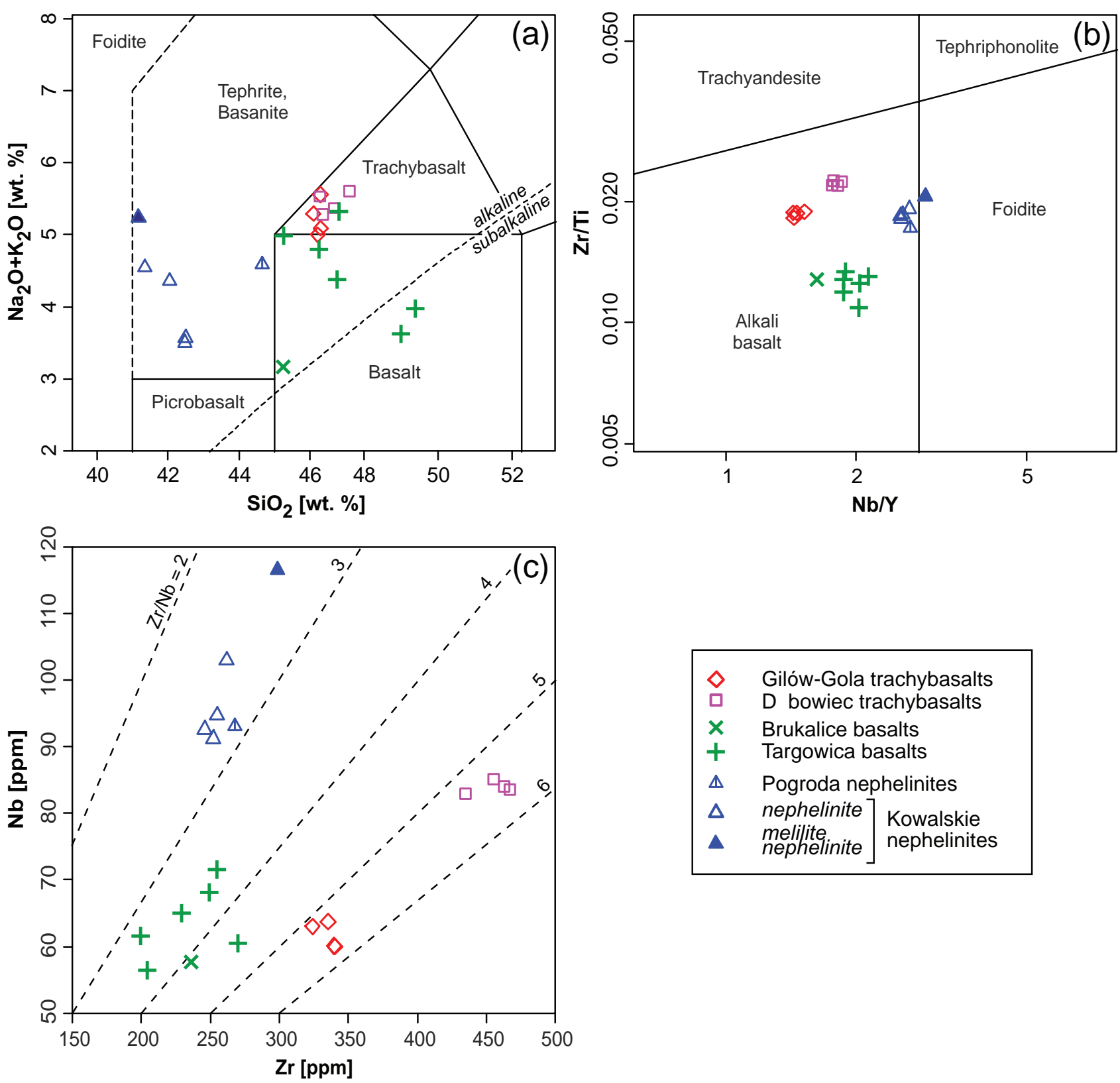

Fig. 5 Chemical classification of the studied rocks: a - zoomed up total alkalis-silica (TAS) diagram (after Le Maitre et al. 2002); $\mathbf{b}$ - part of the $\mathrm{Zr} / \mathrm{TiO}_{2}$ vs. Nb/Y diagram (Pearce 1996); c - binary diagram Nb vs. Zr.

rocks into four clusters, each representing a separate volcanic system.

The differences between nephelinites, basalts and trachybasalts are accentuated in the binary plot of $\mathrm{Nb}$ vs. Zr (Fig. 5c). The Kowalskie and Pogroda nephelinites are characterized by low $\mathrm{Zr} / \mathrm{Nb}$ ratios (below 3) and moderate $\mathrm{Zr}$ contents (c. 250-300 ppm); the Targowica and Brukalice basalts have $\mathrm{Zr} / \mathrm{Nb} \sim 4$ and the lowest contents of $\mathrm{Zr}$ (c. 200-270 ppm). For the Dębowiec and Gilów-Gola trachybasalts, the $\mathrm{Zr} / \mathrm{Nb}$ ratios vary between 5 and 6 and the $\mathrm{Zr}$ contents are the highest (c. $450 \mathrm{ppm}$ and 320-340 ppm, respectively).

Selected major and trace elements are plotted against $\mathrm{MgO}$ in Fig. 6. Some major elements (e.g. Si, Ti, Al) and highly compatible trace elements (e.g. Ni) follow a simple common linear trend for all groups. However, most of trace elements (e.g. $\mathrm{Zr}, \mathrm{Nb}$ ) usually show a more complex variation, such as divergent trends or separate clusters for nephelinites, basalts and trachybasalts. Overall, the Kowalskie and Pogroda nephelinites are characterized by the highest contents of $\mathrm{MgO}$ and the highest $\mathrm{Mg}$ numbers $(\mathrm{Mg} \#=\mathrm{MgO} /(\mathrm{MgO}+\mathrm{FeOt})$, molar proportions; Tab. 2). The basalts and trachybasalts

Fig. 6 Binary plots of selected major and trace elements against $\mathrm{MgO}$ for the volcanic rocks of the SVF. Symbols as in Fig. 5. 

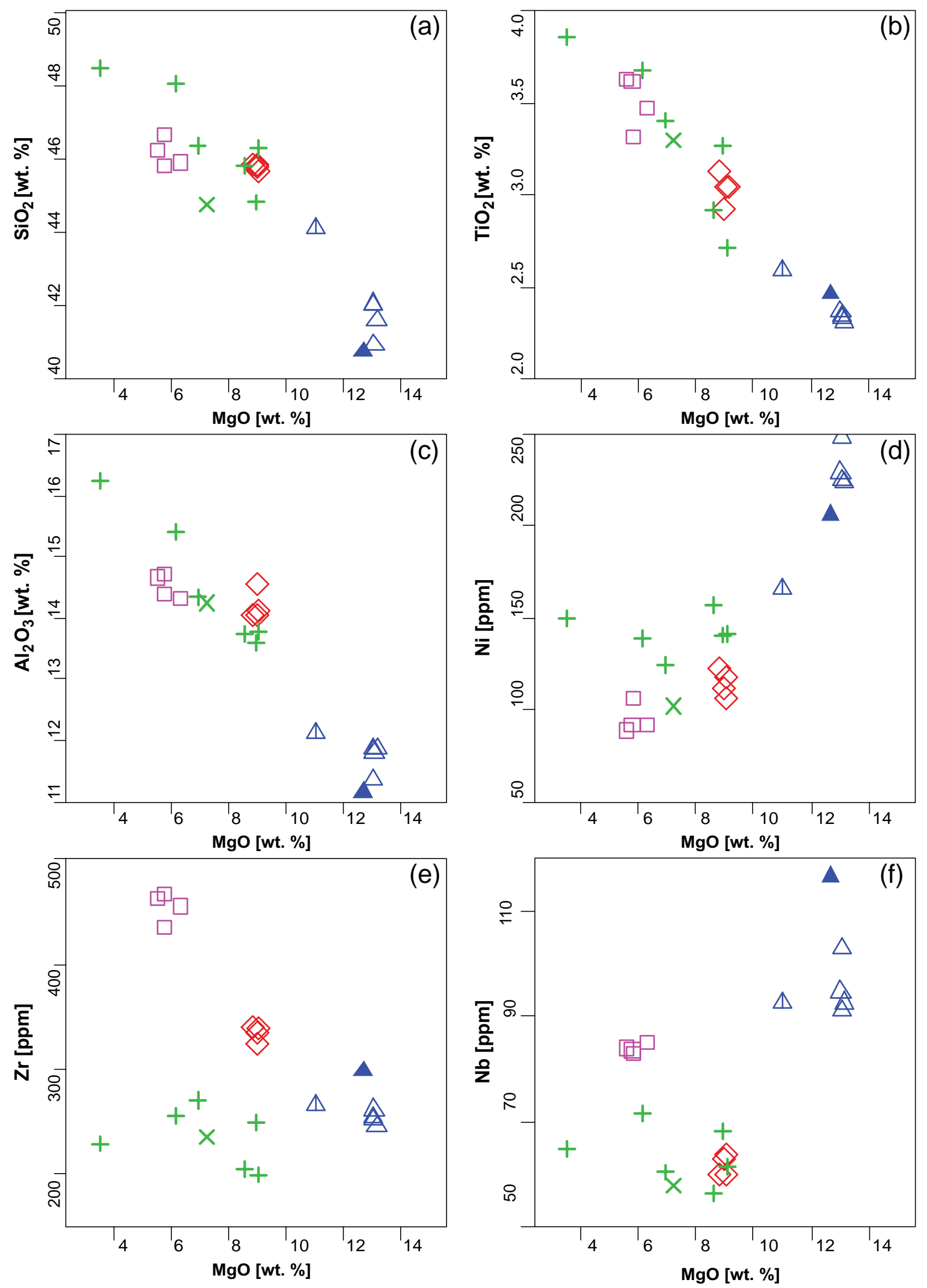
have lower concentrations of $\mathrm{MgO}$ (and $\mathrm{CaO}$ ), but they are enriched in $\mathrm{SiO}_{2}, \mathrm{TiO}_{2}$ and $\mathrm{Al}_{2} \mathrm{O}_{3}$ compared to the nephelinites; $\mathrm{Fe}_{2} \mathrm{O}_{3 \text { (tot.) }}$ contents are broadly similar in all rocks (Tab. 2). Compared to the nephelinites, all basalts and trachybasalts present lower abundances of compatible elements such as $\mathrm{Ni}, \mathrm{Cr}$ and $\mathrm{V}$, and also of several Large Ion Lithophile Elements (LILE; e.g., Sr) and Light Rare Earth Elements (LREE; e.g. Ce), as well as Ta and Nb. The basalts are also depleted in $\mathrm{Zr}$ and $\mathrm{Y}$, whereas the trachybasalts are enriched in these elements relative to the nephelinites (Fig. 6, Tab. 2).
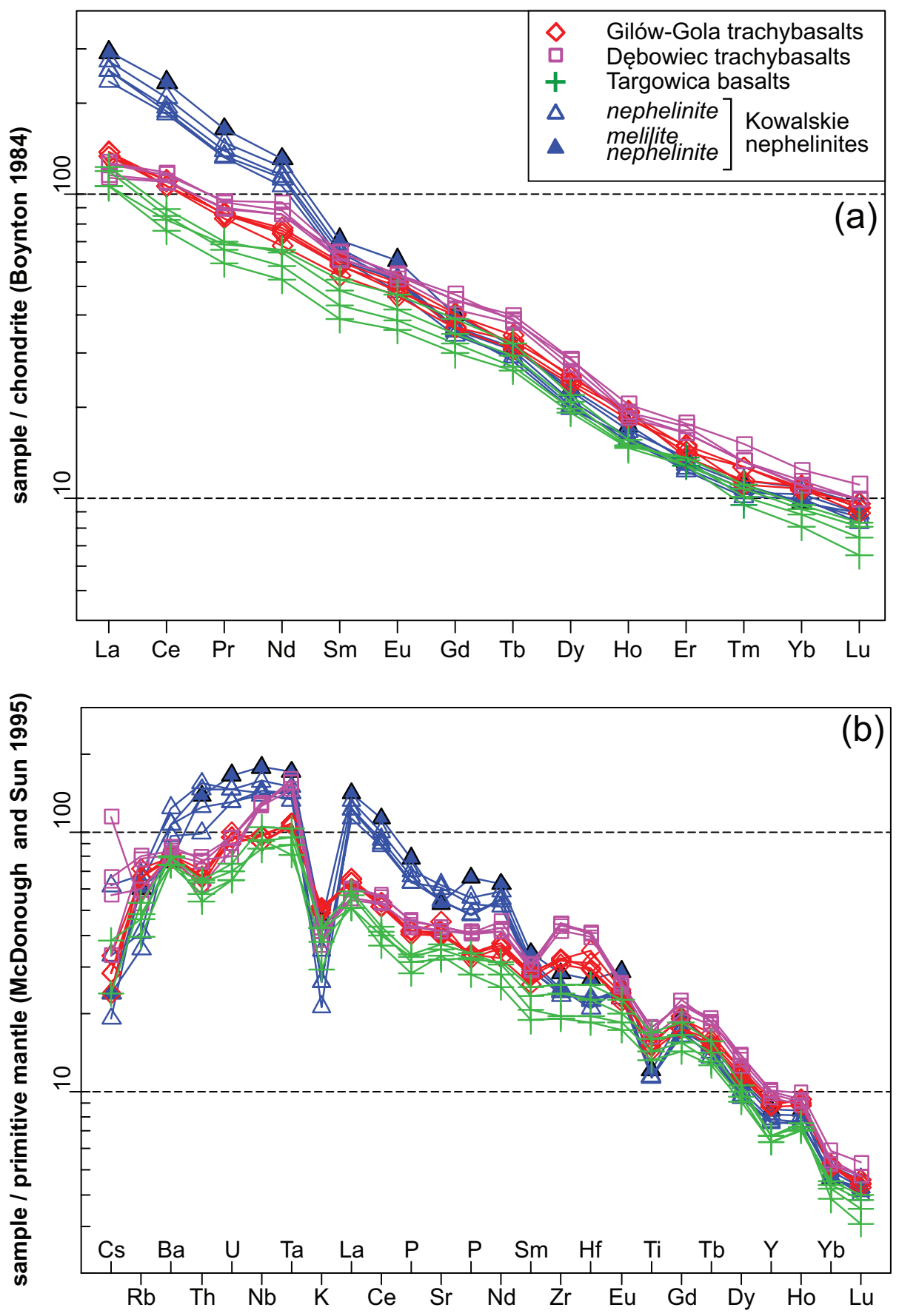

In the chondrite-normalized REE plots (Fig. 7a) all samples show similar Heavy Rare Earth Element (HREE) abundances, mostly 6-10× chondritic values. The nephelinites, however, are characterized by highest abundances of the LREE (La contents up to 300× chondrite), resulting in the steepest patterns. The trends of basalts and trachybasalts are less LREE-enriched, subparallel, with the lowest total REE abundances in the basalts and the highest in the Gilów-Gola trachybasalts. In the primitive mantle-normalized plots (Fig. 7b), all samples share some general features, such as: asymmetrically upward-curved, hill-shaped patterns culminating at $\mathrm{Ta}$ and $\mathrm{Nb}$, pronounced negative anomalies at $\mathrm{K}, \mathrm{Ti}$ and, in some specimens, weaker, variable anomalies at Th, Sr or Zr. The nephelinites are distinct from basalts and trachybasalts in: (1) significantly higher abundances of several incompatible elements ( $\mathrm{Ba}$ to Ta, La to Nd), and (2) deeper negative anomalies at $\mathrm{K}$ and Ti. The differences between basalts and trachybasalts are less pronounced, their trends are subparallel with lower abundances of elements typical of the basalts. Trace-element abundances in the Dębowiec trachybasalts tend to be higher than in the Gilów-Gola trachybasalts.

\section{5. $\mathrm{Sr}-\mathrm{Nd}-\mathrm{Pb}$ isotope geochemistry}

The isotopic data for six representative samples of the SVF lavas are shown in Tab. 3 and illustrated in Fig. 8. Data for other Cenozoic volcanic rocks from the Lower Silesia, the Eger Rift and other locations in the Bohemian Massif are plotted for comparison.

The ${ }^{87} \mathrm{Sr} /{ }^{86} \mathrm{Sr}_{i}$ isotopic ratios of the SVF samples show a narrow range from $c .0 .7031$ in

Fig. 7a - Chondrite-normalized REE patterns (normalization after Boynton 1984). b - Primitive mantle-normalized multi-element patterns (normalization after McDonough and Sun 1995). 
Tab. $3 \mathrm{Sr}$, Nd and $\mathrm{Pb}$ isotopic data for representative samples of the volcanic rocks

\begin{tabular}{|c|c|c|c|c|c|c|}
\hline Sample & 14 & 17 & 363 & 366 & 479 & 623 \\
\hline Rock unit & TB & TB & $\mathrm{KN}$ & $\mathrm{KN}$ & GGT & DT \\
\hline$\left({ }^{87} \mathrm{Rb} /{ }^{86} \mathrm{Sr}\right)_{\mathrm{m}}$ & 0.126319 & 0.126991 & 0.098833 & 0.050625 & 0.141427 & 0.159971 \\
\hline$\left({ }^{87} \mathrm{Sr} /{ }^{86} \mathrm{Sr}\right)_{\mathrm{m}}$ & 0.703289 & 0.703453 & 0.703290 & 0.703297 & 0.703123 & 0.703270 \\
\hline $2 \mathrm{~S}(\mathrm{M})$ & 0.000014 & 0.000015 & 0.000011 & 0.000009 & 0.000011 & 0.000001 \\
\hline$\left({ }^{87} \mathrm{Sr} /{ }^{86} \mathrm{Sr}\right)_{\mathrm{i}}$ & 0.703236 & 0.703399 & 0.703248 & 0.703275 & 0.703063 & 0.703188 \\
\hline$\left({ }^{147} \mathrm{Sm} /{ }^{144} \mathrm{Nd}\right)_{\mathrm{m}}$ & 0.147622 & 0.145876 & 0.106152 & 0.111127 & 0.151805 & 0.136896 \\
\hline$\left({ }^{143} \mathrm{Nd} /{ }^{144} \mathrm{Nd}\right)_{\mathrm{m}}$ & 0.512996 & 0.512960 & 0.512885 & 0.512879 & 0.513009 & 0.512998 \\
\hline $2 \mathrm{~S}(\mathrm{M})$ & 0.000008 & 0.000011 & 0.000004 & 0.000005 & 0.000005 & 0.000005 \\
\hline$\left({ }^{143} \mathrm{Nd} /{ }^{144} \mathrm{Nd}\right)_{\mathrm{i}}$ & 0.512968 & 0.512931 & 0.512864 & 0.512857 & 0.512980 & 0.512970 \\
\hline${ }^{206} \mathrm{~Pb} /{ }^{204} \mathrm{~Pb}$ & 19.8842 & - & 19.9010 & 20.0430 & - & 19.6319 \\
\hline $2 \mathrm{~S}(\mathrm{M})$ & 0.0005 & - & 0.0008 & 0.0006 & - & 0.0008 \\
\hline${ }^{207} \mathrm{~Pb} /{ }^{204} \mathrm{~Pb}$ & 15.6400 & - & 15.6624 & 15.6492 & - & 15.5226 \\
\hline $2 \mathrm{~S}(\mathrm{M})$ & 0.0005 & - & 0.0007 & 0.0005 & - & 0.0010 \\
\hline $2 \mathrm{~S}(\mathrm{M})$ & 0.0011 & - & 0.0017 & 0.0011 & - & 0.0027 \\
\hline
\end{tabular}

Rock units: TB - Targowica basalts, KN - Kowalskie nephelinites, GGT - Gilów-Gola trachybasalts, DT - Dębowiec trachybasalts

$\left({ }^{87} \mathrm{Rb} /{ }^{86} \mathrm{Sr}\right)_{\mathrm{m}},\left({ }^{87} \mathrm{Sr} /{ }^{86} \mathrm{Sr}\right)_{\mathrm{m}},\left({ }^{147} \mathrm{Sm} /{ }^{144} \mathrm{Nd}\right)_{\mathrm{m}},\left({ }^{143} \mathrm{Nd} /{ }^{144} \mathrm{Nd}\right)_{\mathrm{m}}-$ measured ratios

$\left({ }^{87} \mathrm{Sr} /{ }^{86} \mathrm{Sr}\right)_{\mathrm{i}}$ and $\left({ }^{143} \mathrm{Nd} /{ }^{144} \mathrm{Nd}\right)_{\mathrm{i}}$ - initial isotopic ratios calculated for $30 \mathrm{Ma}$

$2 \mathrm{~S}(\mathrm{M})$ - two standard errors of the mean

trachybasalts to 0.7034 in basalts. The ${ }^{143} \mathrm{Nd} /{ }^{144} \mathrm{Nd}_{\mathrm{i}}$ ratios clearly distinguish the nephelinites, showing lower values around 0.51286, from the basalts and trachybasalts, with higher values of 0.51293 to 0.51298 (the highest ratios were measured in two trachybasalt samples). Overall, these $\mathrm{Sr}-\mathrm{Nd}$ isotopic ratios are intermediate between those of the Depleted Mantle (DM) and Bulk Silicate Earth (BSE; Jacobsen and Wasserburg 1980), and similar to these of the HIMU (High- $\mu$ ) reservoir. The Sr-Nd isotopic ratios of SVF volcanic rocks are similar to the previously published data from Lower Silesia (Blusztajn and Hart 1989). The values reported here for two trachybasalts and one basalt rank among the lowest ${ }^{87} \mathrm{Sr} /{ }^{86} \mathrm{Sr}$ and the highest ${ }^{143} \mathrm{Nd} /{ }^{144} \mathrm{Nd}$ ratios compared to the Eger Rift, or other locations within the Bohemian Massif (Rapprich and Holub 2008; Cajz et al. 2009; Holub et al. 2010; Ulrych et al. 2016), and also within the Central European Volcanic Province (Jung and Masberg 1998; Lustrino and Wilson 2007). The Sr-Nd isotopic compositions of the nephelinites are less extreme, and resemble the samples from the Eger Rift (Cajz et al. 2009; Holub et al. 2010).

The $\mathrm{Pb}$ isotopic ratios were determined in four samples; ${ }^{206} \mathrm{~Pb} /{ }^{204} \mathrm{~Pb}$ displays a rather limited range from c. 19.6 to $20.0,{ }^{207} \mathrm{~Pb} /{ }^{204} \mathrm{~Pb}$ in three samples clusters around c. 15.65 and in one (Dębowiec trachybasalt) is lower, c. 15.52. Overall, the $\mathrm{Nd}, \mathrm{Sr}$ and $\mathrm{Pb}$ isotopic ratios highlight the distinctive characteristics of the nephelinites compared to the basalts and trachybasalts. In the ${ }^{143} \mathrm{Nd} /{ }^{144} \mathrm{Nd}-{ }^{206} \mathrm{~Pb} /{ }^{204} \mathrm{~Pb}$ diagram (Fig. 8b), all analyzed samples reveal rather radiogenic compositions and plot within the DM-HIMU-EM1-EM2 polygon, close to the DM-HIMU side. The SVF basalt and trachybasalt, together with the other Lower Silesian samples, show more pronounced DM characteristics, whereas the SVF nephelinites, similar to samples from the Eger Rift, are more akin the HIMU end-member. Compared to many other samples from the Lower Silesia and elsewhere in the Bohemian Massif, the rocks from the SVF plot away the EM1 and EM2 end-members, indicating the weakest influence of the enriched mantle sources. Similar relationships are seen in the ${ }^{207} \mathrm{~Pb} /{ }^{204} \mathrm{~Pb}-{ }^{206} \mathrm{~Pb} /{ }^{204} \mathrm{~Pb}$ diagram (Fig. 8c). Three samples from the SVF fall very close to, and the trachybasalt significantly below, the Northern Hemisphere Reference Line (NHRL), far from the EM1-EM2 end members.

\section{Discussion}

\subsection{Differentiation processes}

According to Wilson (1989, and references therein), primary basaltic (sensu lato) melts derived from mantle peridotites are characterized by $\mathrm{Mg} \#>70, \mathrm{Ni}>400-500$ $\mathrm{ppm}$ and $\mathrm{Cr}>1000 \mathrm{ppm}$. The volcanic rocks of the SVF show Mg\# and compatible-element contents (Tab. 2) significantly lower, which may be linked to some fractional crystallization of mafic minerals. The felsic xenoliths and quartz xenocrysts, apparently derived from crustal rocks, may indicate some influence of crustal contamination processes. On the other hand, millimetre-sized fragments of peridotite xenoliths are relatively common in these volcanic rocks and point to rather fast transport of magma from mantle depths to the surface, without significant differentiation in shallow-level magma chambers. Also, the overall composition of SVF volcanic rocks and their $\mathrm{Sr}-\mathrm{Nd}$ isotopic ratios, different from typical crustal values, argue against significant differentiation or contami- 


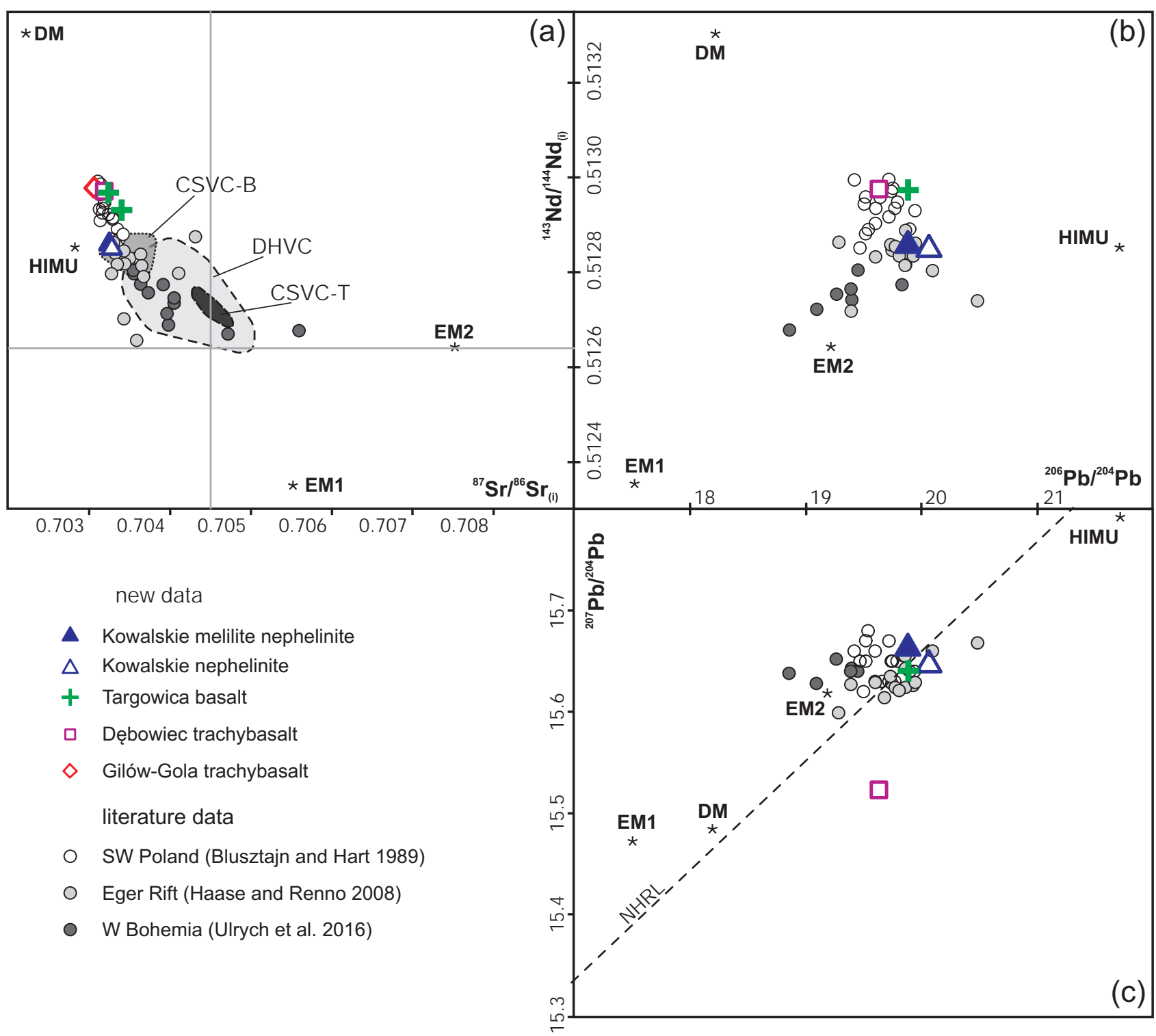

Fig. 8 Plots of $\mathrm{Nd}, \mathrm{Sr}, \mathrm{Pb}$ isotopic ratios for the Strzelin Volcanic Field in comparison with published data from the Bohemian Massif. a $\left({ }^{143} \mathrm{Nd} /{ }^{144} \mathrm{Nd}\right)_{\mathrm{i}}$ vs. $\left({ }^{87} \mathrm{Sr} /{ }^{86} \mathrm{Sr}\right)_{\mathrm{i}} ; \mathbf{b}-\left({ }^{143} \mathrm{Nd} /{ }^{144} \mathrm{Nd}\right)_{\mathrm{i}}$ vs. ${ }^{206} \mathrm{~Pb} /{ }^{204} \mathrm{~Pb} ; \mathbf{c}-{ }^{207} \mathrm{~Pb} / 204 \mathrm{~Pb}$ vs. ${ }^{206} \mathrm{~Pb} /{ }^{204} \mathrm{~Pb}$. Sr and Nd ratios were re-calculated to initial ratios at $30 \mathrm{Ma}$, whereas $\mathrm{Pb}$ isotopes are presented as measuered values. CSVC-B - České Středohoří Volcanic Complex basanites (Cajz et al. 2009), CSVC-T - České Středohoří Volcanic Complex trachybasalts (from Cajz et al. 2009), DHVC - Doupovské Hory Volcanic Complex (Rapprich and Holub 2008 and Holub et al. 2010). DM - Depleted Mantle (Zindler and Hart 1986), EM1 - Enriched Mantle type 1 (Zindler and Hart 1986), EM2 - Enriched Mantle type 2 (Zindler and Hart 1986), HIMU - High- $\mu$ Mantle (Zindler and Hart 1986). BSE - Bulk Silicate Earth (Jacobsen and Wasserburg 1980), NHRL - Northern Hemisphere Reference Line (Hart 1984). Reservoirs are not age-corrected.

nation of the parental melts. Overall, the above evidence is consistent with limited fractional crystallization and very limited contamination, if any.

Fractional crystallization of, predominantly, olivine and clinopyroxene, the main phenocryst phases of the volcanic rocks, seems the most likely process which could have affected the primary magma compositions. Possible effects of fractional crystallization were evaluated using numerical modelling (Fig. 9). The calculated geochemical trends were derived from mass balance (the lever rule) for the major elements and the Rayleigh fractional crystallization equation for trace elements. The assimilation-fractional crystallization (AFC) equation was used for modelling fractional crystallization coupled with replenishment, with the replenishing magma treated as "contaminant". The approach and equations were given in Wilson (1989) and Rollinson (1993) and in papers cited therein. Modelling was carried out for selected major and trace elements, representative of compatible and incompatible components 

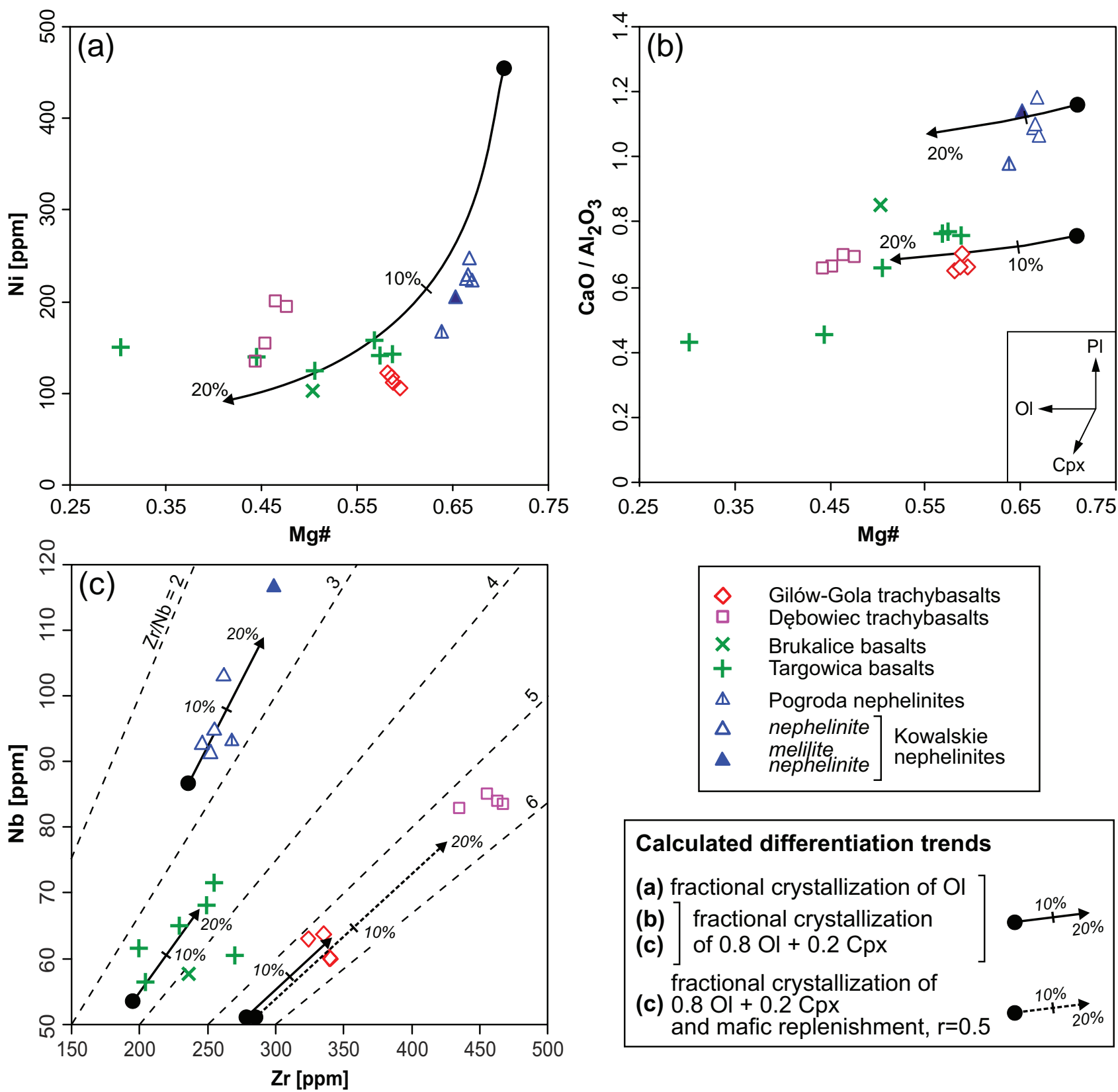

\begin{tabular}{|c|c|c|}
\hline $\begin{array}{l}\diamond \\
\square\end{array}$ & \multicolumn{2}{|c|}{$\begin{array}{l}\text { Gilów-Gola trachybasalts } \\
\text { Dębowiec trachybasalts }\end{array}$} \\
\hline $\begin{array}{l}x \\
+\end{array}$ & \multicolumn{2}{|c|}{$\begin{array}{l}\text { Brukalice basalts } \\
\text { Targowica basalts }\end{array}$} \\
\hline$\Delta$ & \multicolumn{2}{|c|}{ Pogroda nephelinites } \\
\hline $\begin{array}{l}\Delta \\
\Delta\end{array}$ & $\begin{array}{l}\text { nephelinite } \\
\text { melilite } \\
\text { nephelinite }\end{array}$ & $\begin{array}{l}\text { Kowalskie } \\
\text { nephelinites }\end{array}$ \\
\hline
\end{tabular}

\section{Calculated differentiation trends}

(a) fractional crystallization of $\mathrm{OI}$

(b) fractional crystallization

(c) of $0.8 \mathrm{OI}+0.2 \mathrm{Cpx}$

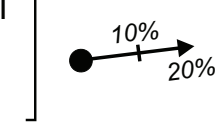

fractional crystallization of

(c) $0.8 \mathrm{Ol}+0.2 \mathrm{Cpx}$ and mafic replenishment, $r=0.5$

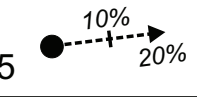

Fig. 9 Numerical models of differentiation trends for the SVF volcanic rocks for selected major and trace elements: $\mathbf{a}-\mathrm{Ni}-\mathrm{Mg} \# \mathrm{plot}$; $\mathbf{b}-\mathrm{CaO} /$ $\mathrm{Al}_{2} \mathrm{O}_{3}-\mathrm{Mg} \#$ plot (inset shows expected melt evolution trends due to fractional crystallization of calcic plagioclase $\left(\mathrm{An}{ }_{80-50}\right), \mathrm{Pl}, \mathrm{Mg}-\mathrm{rich}_{0}$ olivine $\left(\mathrm{Fo}_{90-80}\right), \mathrm{Ol}$, and clinopyroxene (diopside - ideal composition), $\mathrm{Cpx} ; \mathrm{c}-\mathrm{Nb}-\mathrm{Zr}$ plot. Fractional crystallization and fractional crystallization coupled with replenishment (assuming replenishment/fractionation ratio $\mathrm{r}=0.5$ ) were modelled. Initial melt compositions in (a) and (b) were $\mathrm{Mg} \#=0.7$, $\mathrm{Ni}=450 \mathrm{ppm}, \mathrm{CaO} / \mathrm{Al}_{2} \mathrm{O}_{3}=1.16$ or 0.76 . Fractionating minerals: $\mathrm{Ol}$ in (a), $0.8 \mathrm{Ol}+0.2 \mathrm{Cpx}$ in (b) and (c). Mineral compositions: $\mathrm{Ol}=\mathrm{Fo}_{88}$ (equilibrium composition for primary melt with $\mathrm{Mg} \#=0.7), \mathrm{Cpx}=$ ideal composition of diopside. Partition coefficient for $\mathrm{Ni}$ in $\mathrm{Ol}$ in basaltic melts is 8 (based on Wilson 1989; Rollinson 1993, and references therein); partition coefficients for $\mathrm{Zr}$ and $\mathrm{Nb}$ are given in Tab. 4.

of the magmas. All parameters used in calculation are given in the caption of Fig. 9.

Figure 9a shows the variation of $\mathrm{Ni}$ vs. Mg\# in the SVF rocks together with differentiation trend of a possible primary magma due to fractional crystallization of olivine. Addition of small amounts of other minerals (e.g. clinopyroxene) into the fractionating mineral assemblage has a rather minor effect on the calculated $\mathrm{Ni}-\mathrm{Mg} \#$ trends. Thus, the SVF magmas could have evolved by the olivine-dominated fractional crystallization. The nephelinites represent less evolved magmas, affected by c. $10 \%$ of olivine-dominated fractional crystallization, whereas the basalts and trachybasalts correspond to more evolved magmas, affected by up to $c$. $20 \%$ of olivine-dominated fractional crystallization. 
In the plot of $\mathrm{CaO} / \mathrm{Al}_{2} \mathrm{O}_{3}$ vs. $\mathrm{Mg \#} \mathrm{(Fig.} \mathrm{9b),} \mathrm{the} \mathrm{effects}$ of fractional crystallization of olivine, clinopyroxene and plagioclase can be evaluated. As indicated by the vectors in the lower right corner of this plot, fractionation of olivine results in decrease of $\mathrm{Mg \#}$ but no change in $\mathrm{Ca} /$ $\mathrm{Al}$ ratio of the magma (horizontal vector $\mathrm{Ol}$ ); fractionation of calcic plagioclase leads to the increase in $\mathrm{Ca} / \mathrm{Al}$ ratio but the $\mathrm{Mg} \#$ of the magma is not changed (vertical vector $\mathrm{Pl}$ ) and fractionation of clinopyroxene results in a strong decrease of $\mathrm{Ca} / \mathrm{Al}$ ratio and small decrease of Mg\# (steep vector Cpx). In this diagram the SVF volcanic rocks plot in two distinct groups: the nephelinites, and the basalts with trachybasalts. The subhorizontal trend for the latter group is suggestive of olivine-dominated fractionation, possibly with some clinopyroxene also involved. The influence of plagioclase fractionation can be excluded, as also reflected in the absence of Euanomaly in chondrite-normalized REE patterns (Fig. 7a). Two basalt samples that plot away from the rest, at the lowest $\mathrm{Mg} \#$ values and $\mathrm{CaO} / \mathrm{Al}_{2} \mathrm{O}_{3}$ ratios, are partly altered and thus probably affected by post-magmatic element mobility. The nephelinites form a tight cluster rather than a trend, with Pogroda nephelinite sample shifted to slightly lower $\mathrm{Mg} \#$ and $\mathrm{CaO} / \mathrm{Al}_{2} \mathrm{O}_{3}$, possibly due to some alteration. Potentially, the nephelinites and basalts-trachybasalts could be linked to different degrees of differentiation of a single parental magma with a high $\mathrm{Mg} \#$ and $\mathrm{CaO} / \mathrm{Al}_{2} \mathrm{O}_{3}$. However, such a model (not shown) would require clinopyroxene-dominated fractional crystallization, which would be inconsistent with the other geochemical constraints, such as the Ni vs. Mg\# variation (implying olivine-dominated fractionation from Ni-rich parental magma). Therefore, the chemical trends defined by the SVF samples in the $\mathrm{CaO} / \mathrm{Al}_{2} \mathrm{O}_{3}$ vs. $\mathrm{Mg \#}$ plot can be best modelled as the effect of fractional crystallization of olivine with subordinate clinopyroxene (e.g., weight fractions 0.8 and 0.2 , respectively; arbitrary values), from primary magmas with $\mathrm{Mg \#}$ value close to 0.7 and $\mathrm{CaO} / \mathrm{Al}_{2} \mathrm{O}_{3}$ ratio similar to the observed rock compositions. It follows that at least two distinct types of primary magmas, one for nephelinites, the other for basalts-trachybasalts, are required.

The role of different primary magmas and distinctive fractionation paths for various groups of rocks are further evaluated in the Nb-Zr plot (Fig. 9c). In this diagram, the SVF nephelinites, basalts and trachybasalts plot along separate trends with different $\mathrm{Zr} / \mathrm{Nb}$ ratios. Zirconium and $\mathrm{Nb}$ are incompatible in mineral assemblages that may crystallize from primitive, silica-poor magmas and therefore fractional crystallization does not significantly influence the ratio of these elements. These relationships imply that each group of the SVF rocks originated from primary magmas with a different $\mathrm{Zr} / \mathrm{Nb}$ ratio. These parental compositions must lie along trends of constant $\mathrm{Zr} / \mathrm{Nb}$ ratios, not far from the observed rock compositions (the degree of fractional crystallization is less that 10-20\%, see Fig. 9a), at lower $\mathrm{Zr}$ and $\mathrm{Nb}$ (e.g., $\mathrm{Zr}=235 \mathrm{ppm}, \mathrm{Nb}$ $=85 \mathrm{ppm}$ for nephelinites; $\mathrm{Zr}=190 \mathrm{ppm}, \mathrm{Nb}=53 \mathrm{ppm}$ for basalts; $\mathrm{Zr}=275 \mathrm{ppm}, \mathrm{Nb}=51 \mathrm{ppm}$ for trachybasalts). Possible fractional crystallization trends calculated using these constraints and olivine-dominated mineral assemblages fit well the observed variation for the nephelinites, the basalts, and the Gilów-Gola trachybasalts (Fig. 9c). However, in the nephelinites the relatively wide range of $\mathrm{Zr}$ and $\mathrm{Nb}$ contents may be an effect of not only fractional crystallization, but also variable degrees of partial melting. In the case of Dębowiec trachybasalts, their high $\mathrm{Zr}$ and $\mathrm{Nb}$ contents (compared to Gilów-Gola trachybasalts) can be either explained by derivation from $\mathrm{Zr}$ - and Nb-rich parental magma (i.e. $400 \mathrm{ppm}$ of $\mathrm{Zr}, 70 \mathrm{ppm}$ of $\mathrm{Nb}$ ) or, more consistently with the relatively low magnesium numbers in these rocks (see Fig. 9a), by more advanced differentiation. It can be suggested that the Dębowiec magmas evolved due to fractional crystallization coupled with replenishment of the magmatic system with the primitive magma. As shown by the calculated trend $(20 \%$ of fractional crystallization coupled with replenishment, with replenishment to fractional crystallization ratio $r=0.5$ suggested by trial and error fitting), in this type of differentiation the $\mathrm{Zr} / \mathrm{Nb}$ ratio remains unmodified but, at similar degree of differentiation, the $\mathrm{Zr}$ and $\mathrm{Nb}$ contents rise to higher levels.

\subsection{Mantle sources of magma, partial melting processes and regional constraints on magma origin}

The models discussed above rise questions about the composition(s) and origin of the parental magmas in the SVF, including such problems as the role of source heterogeneity, the geochemical and mineralogical characteristics of the mantle sources, the degrees of partial melting and the depths of magma segregation from the source (garnet- vs. spinel-peridotite stability fields). These questions were addressed using numerical modelling of selected trace elements (Zr, Nb, Y, Ce and Yb; Fig. $10)$. The non-modal batch melting equation was applied (Wilson 1989; Rollinson 1993). The Nd-Sr-Pb isotopic data (Fig. 8) constrain the mantle sources: the magmas were derived from a heterogeneous source which may be approximated as a mixture of the DM and HIMU endmembers, with negligible role of the EM end-members. The trace-element composition of the depleted mantle end-member used here is the "Enriched Depleted MORB Mantle" (EDMM) of Workman and Hart (2005): a mildly depleted mantle, enriched relative to the average depleted mantle composition. The trace-element composition of the HIMU end-member is not known exactly but it is generally considered to represent the oceanic lithosphere 

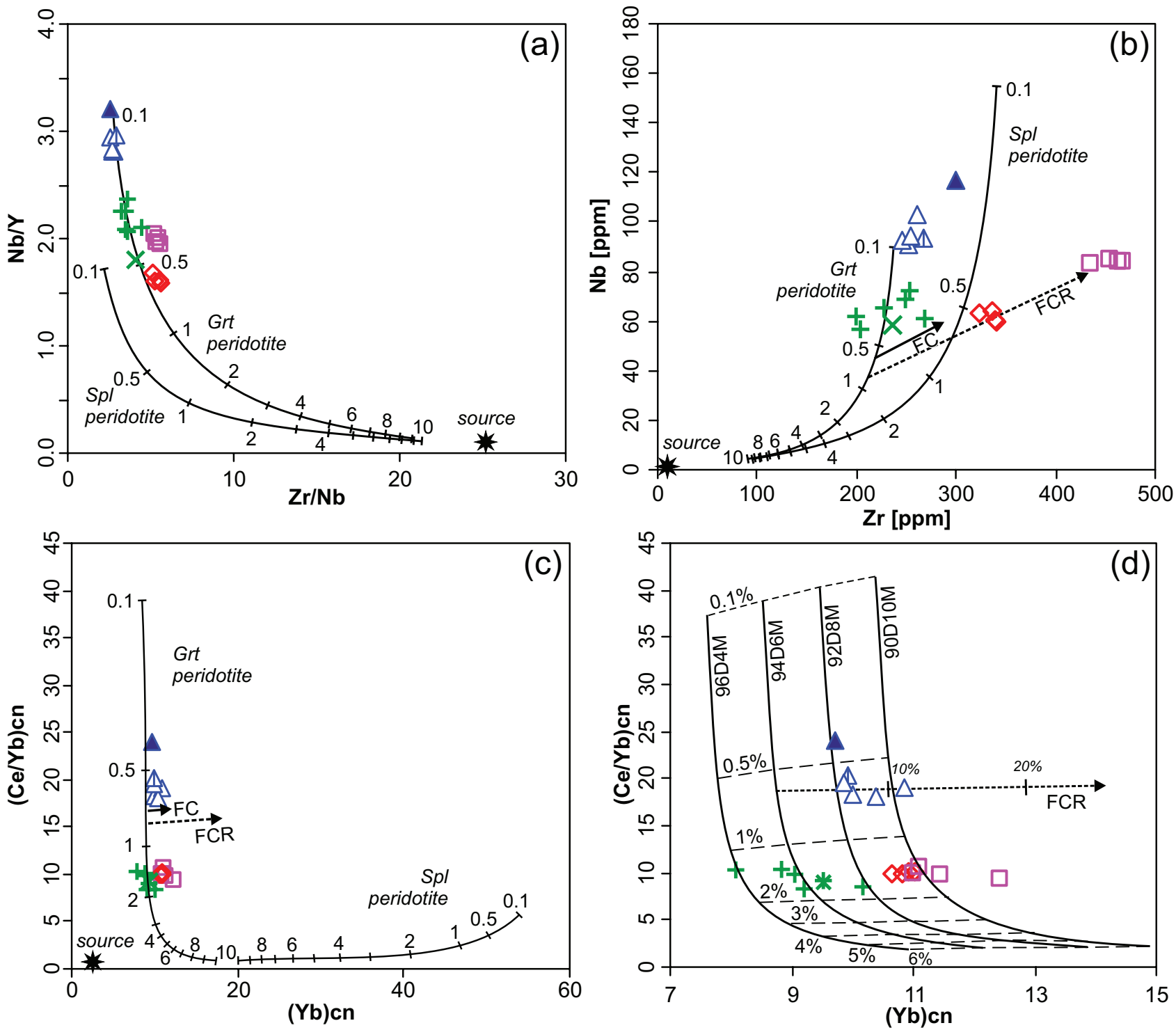

FC: fractional crystallization of $0.8 \mathrm{OI}+0.2 \mathrm{Cpx}$, starting at $0.6 \%$ partial melt of Grt peridotite

FCR: fractional crystallization of $0.8 \mathrm{OI}+0.2 \mathrm{Cpx}$, starting at $0.8 \%$ partial melt of Grt peridotite, coupled with replenishment, $r=0.7$

\begin{tabular}{|c|c|}
\hline $\begin{array}{l}\diamond \\
\square\end{array}$ & $\begin{array}{l}\text { Gilów-Gola Trachybasalts } \\
\text { Dębowiec Trachybasalts }\end{array}$ \\
\hline $\begin{array}{l}x \\
+\end{array}$ & $\begin{array}{l}\text { Brukalice Basalts } \\
\text { Targowica Basalts }\end{array}$ \\
\hline$\Delta$ & Pogroda Nephelinites \\
\hline$\Delta$ & \begin{tabular}{l|l} 
nephelinite & Żelowice- \\
melilite & Kowalskie \\
nephelinite & Nephelinites
\end{tabular} \\
\hline
\end{tabular}

Fig. 10 The trace-element based melting models for the SVF volcanic rocks. a - Nb/Y vs. Zr/Nb; b - Nb vs Zr; c $-(\mathrm{Ce} / \mathrm{Yb}) \mathrm{cn}$ vs. (Yb)cn, where cn - chondrite-normalized values (normalization after Boynton 1984). The melting curves in a, b and c assume a mixed DM/HIMU source (modelled as 94 wt. \% EDMM + 6 wt. \% MORB, see text), in spinel or a garnet lherzolite stability fields. Ticks labelled " $0.1,0.5,1, \ldots$ " along the melting curves indicate degrees of partial melting, in wt \% of melt. In the plots b and c, trends of fractional crystallization and fractional crystallization coupled with primitive magma replenishment are also shown to indicate the possible influence of shallow-level differentiation (these trends are not shown in the plot a, because the $\mathrm{Nb} / \mathrm{Y}$ and $\mathrm{Zr} / \mathrm{Nb}$ ratios are not significantly affected by fractional crystallization). $\mathbf{d}-\mathrm{A}$ family of melting curves of a garnet lherzolite in the chondrite-normalized $(\mathrm{Ce} / \mathrm{Yb}) \mathrm{cn}-(\mathrm{Yb}) \mathrm{cn}$ plot (normalization after Boynton 1984), calculated for variable trace-element compositions of the source (solid lines labelled 90D10M $=90$ wt. \% EDMM + 10 wt. \% MORB, to 96D4M $=96 \mathrm{wt}$. $\% \mathrm{EDMM}+4 \mathrm{wt}$. $\%$ MORB) and contoured for various degrees of partial melting (dashed lines labelled $0.1 \%$ to $6 \%$ ). The vector FCR indicates possible effects of differentiation, as in plots a, b. Data used in modelling are given in Tab. 4; other details in text. 
Partition coefficients (Kostopoulos and James 1992)

\begin{tabular}{llllll}
\hline & \multicolumn{1}{c}{ Ol } & Opx & \multicolumn{1}{c}{ Cpx } & \multicolumn{1}{c}{ Spl } & Grt \\
\hline $\mathrm{Zr}$ & 0.01 & 0.03 & 0.16 & 0.05 & 0.32 \\
$\mathrm{Nb}$ & 0.0001 & 0.001 & 0.015 & 0.0001 & 0.04 \\
$\mathrm{Y}$ & 0.01 & 0.1 & 0.2 & 0.0078 & 2.2885 \\
$\mathrm{Ce}$ & 0.000008 & 0.00105 & 0.0389 & 0.000008 & 0.0014 \\
$\mathrm{Yb}$ & 0.0194 & 0.0631 & 0.19 & 0.00032 & 4.7 \\
\hline
\end{tabular}

Mineral phases and melting modes of mantle sources; values are weight fractions (Harangi 2001)

\begin{tabular}{lccccc}
\hline Spl peridotite & Ol & Opx & Cpx & Spl & Grt \\
\hline proportions of phases & 0.580 & 0.300 & 0.100 & 0.020 & 0 \\
contribution to melt & 0.012 & 0.081 & 0.764 & 0.143 & 0 \\
\hline Grt peridotite & Ol & Opx & Cpx & Spl & Grt \\
\hline proportions of phases & 0.599 & 0.255 & 0.088 & 0 & 0.058 \\
contribution to melt & 0.012 & 0.081 & 0.364 & 0 & 0.543 \\
\hline
\end{tabular}

Trace-element compositions of mantle sources (ppm)

\begin{tabular}{lclccc}
\hline & $\mathrm{Zr}$ & $\mathrm{Nb}$ & $\mathrm{Y}$ & $\mathrm{Ce}$ & $\mathrm{Yb}$ \\
\hline EDMM (Workman and Hart 2005) & 6.087 & 0.246 & 3.548 & 0.726 & 0.382 \\
MORB (Pearce 1983) & 90.0 & 3.5 & 30.0 & 10.0 & 3.4 \\
$96 \%$ EDMM + 4 \% MORB & 9.44 & 0.38 & 4.61 & 1.10 & 0.50 \\
$94 \%$ EDMM + 6 \% MORB & 11.12 & 0.44 & 5.14 & 1.28 & 0.56 \\
$92 \%$ EDMM + 8 \% MORB & 12.80 & 0.51 & 5.66 & 1.47 & 0.62 \\
$90 \%$ EDMM + $10 \%$ MORB & 14.48 & 0.57 & 6.19 & 1.65 & 0.68
\end{tabular}

Abbreviations: Ol - olivine, Opx - orthopyroxene, Cpx - clinopyroxene, Spl - spinel, Grt - garnet EDMM - Enriched Depleted MORB Mantle, MORB - Mid-Ocean Ridge Basalt
Tab. 4 Data used in numerical modelling of partial melting and differentiation processes

and $\mathrm{Yb}$, however, increase during differentiation, resulting in certain shift from the primary position along the FC-FCR trends shown. From Fig. 10a-c it is clear that the SVF samples fit well the melting curves of the garnet lherzolite and plot away from spinel lherzolite melting curves. The shift of trachybasalt samples to the high $\mathrm{Zr}$ and $\mathrm{Nb}$ contents in Fig. 10b can be best linked to the differentiation processes and not to the melting in the spinel peridotite facies, consistently with the position of these trachybasalt samples in $\mathrm{Nb} / \mathrm{Y}$ vs. Zr/Nb and $\mathrm{Ce} / \mathrm{Yb}$ vs. Yb plots (Fig. 10a and c). From these models it is concluded that the parental magmas in the SVF originated from a heterogeneous DM/HIMU garnet peridotite by low degrees of partial melting, below 1-2 \%. There are some differences in the calculated degrees of partial melting for recycled into the mantle (e.g. Willbold and Stracke 2006). Thus, the HIMU component was approximated here by the MORB composition of Pearce (1983). This simplistic approach has some limitation, e.g. due to possible changes in MORB chemistry caused by alteration and metamorphism before it is recycled back into the mantle (e.g., Bebout 1995; Castro et al. 1996). However, the elements used in modelling (i.e. Zr, Nb, Y, Ce and Yb) may be considered immobile to weakly-mobile in these types of alteration. Using the above constraints, the source of the SVF magmas was modelled as a mixture of EDMM with a small amount of MORB; the latter corresponds to a larger proportion of the HIMU component, representing MORB 'diluted' in ambient mantle. The calculated traceelement compositions of the source, together with other parameters used in the modelling, are given in Tab. 4 .

In Fig. 10a-c, the trace-element data for the SVF volcanic rocks are plotted together with calculated melting curves of the mixed DM/HIMU source (modelled as $94 \% \mathrm{EDMM}+6 \% \mathrm{MORB})$, assuming either a spinel lherzolite or a garnet lherzolite source (Tab. 4). In addition, representative differentiation trends are plotted in Fig. 10b and 10c to illustrate the effects of fractional crystallization and mafic replenishment on the element contents and ratios discussed. The $\mathrm{Nb} / \mathrm{Y}, \mathrm{Zr} / \mathrm{Nb}, \mathrm{Ce} /$ $\mathrm{Yb}$ ratios are not modified by fractional crystallization of olivine with clinopyroxene. The contents of $\mathrm{Zr}$, Nb various pairs of elements, but the relative positions of the samples along the melting curves are retained. The values obtained from the REE models may be closer to reality, as those for $\mathrm{Nb}, \mathrm{Zr}$ and $\mathrm{Y}$ seem very low.

The roles of source heterogeneity and variable degrees of partial melting are further illustrated in Fig. 10d. This diagram is an enlarged section of Fig. 10c and shows a family of melting curves of a garnet lherzolite source calculated for variable proportions of the HIMU and DM end-members, $90 \% \mathrm{EDMM}+10 \% \mathrm{MORB}$ to $96 \%$ EDMM $+4 \%$ MORB. The "melting field" between the extreme melting curves is contoured for various degrees of partial melting, from $0.1 \%$ to $6 \%$. In addition, a trend of fractional crystallization coupled with replenishment illustrates the possible influence of shallow-level differentiation: the $\mathrm{Ce} / \mathrm{Yb}$ ratio is practically unaffected, but $\mathrm{Yb}$ content increases with differentiation (the effect of fractional crystallization alone, not plotted here for clarity, would be significantly weaker, cf. Fig. 10c). This shift is of relatively minor importance for the less evolved nephelinites, but it is more significant for the more evolved trachybasalts. From the relationships in Fig. 10d (and consistently with the isotope data in Fig. 8) it is concluded that both the source heterogeneity and different degrees of partial melting contributed to the diversity of the SVF magmas. The nephelinitic ones originated from a source with a stronger HIMU signature 
(higher proportion of recycled MORB in the source) at low degrees of partial melting (c. $0.5 \%$ ). The variation of $\mathrm{Ce} / \mathrm{Yb}$ in the nephelinites may partly reflect variable degrees of partial melting recorded by lava samples from different localities. In particular, the melilite nephelinite could have originated at the lowest degree of partial melting, below $0.5 \%$. The increased $\mathrm{Yb}$ contents in some specimens, on the other hand, may primarily reflect a more advanced shallow-level differentiation or, less likely, an increased contribution of the HIMU end-member. Compared to the nephelinites, the basalts represent more evolved melts and thus the subhorizontal trend defined by these samples is best explained by the influence of shallow-level differentiation. Considering the possible scale of this shift, the primary magmas of the basalts can be linked with $c .1 \%$ of melting of more depleted source compared to the nephelinites (smaller proportion of recycled MORB component in the source). Parental magmas of the trachybasalts, which show even stronger effects of the shallow-level differentiation (more advanced fractional crystallization coupled with replenishment) originated from a broadly similar source as basalts, and at similar degrees of partial melting (c. $1 \%$ ). However, it seems also likely that some differences in parental magma composition between basalts and trachybasalts did exist, as indicated by the isotopic ratios, showing the strongest DM signature in the trachybasalts (Fig. 8), but the trace-element differences were partly overprinted by the shallow-level differentiation.

The relationships discussed above point to the association of the stronger HIMU signature with lower degrees of partial melting (in the nephelinites), and of the more prominent DM signature with larger degrees of partial melting (in the basalts and trachybasalts). Nevertheless, the trace-element modelling indicates segregation of all magma types of the SVF within the garnet peridotite stability field. According to Wood et al. (2013), garnet is stable in fertile peridotites at solidus temperatures at depths greater than $c$. $85 \mathrm{~km}$. The present-day lithosphere-asthenosphere boundary is located $90-100 \mathrm{~km}$ (Puziewicz et al. 2012) or c. 100-105 km (Geisler et al. 2012) below the SVF, but could have been at $c$. $70 \mathrm{~km}$ at the time when volcanic activity occurred (Puziewicz et al. 2015). Considering the geochemical modelling and the geophysical constraints it is likely that the magmas under the SVF originated predominantly in the asthenospheric mantle, close to the base of lithosphere, or in the lowermost lithospheric mantle. The asthenospheric mantle as the main magma source in the CEVP was suggested by several previous studies (Ladenberger et al. 2006; Wilson and Downes 2006; Lustrino and Wilson 2007).

It remains rather a matter of speculation what the spatial relationships of the DM and HIMU components might have been under the SVF. For instance, the close association in space and time of lavas with variable HIMU and DM signatures, in eruptive products of adjacent small monogenetic volcanoes, may suggest melting of a mantle source with small-scale heterogeneities, e.g., a rising diapir of 'marble-cake' mantle with HIMU domains dispersed in a DM matrix (Allègre and Turcotte 1986), or melting of depleted mantle hosting veins or pods of solidified melts with HIMU characteristics (Wilson 1989 and references therein). The geochemical variation in the SVF can be linked to a progressive melting in a rising mantle diapir. The nephelinites may represent melts segregated at a greater depth, at lower degree of melting, and thus bear a stronger signature of the more fusible and 'fertile' HIMU component, whereas the basalts and trachybasalts would correspond to magmas segregated at a shallower depth after a higher degree of melting, with stronger contribution of the less fertile DM component.

The models discussed above explain well the key isotopic and trace-element signatures of the SVF volcanic rocks. In particular, the enrichment in LREE and other incompatible elements (e.g. Nb, Ta), partly contrasting with the mildly depleted isotopic signatures in the SVF volcanic rocks, can be linked to the relatively fertile source composition (the HIMU component involved) as well as to low degrees of partial melting in the presence of garnet. There seems to be no need to postulate any additional metasomatic enrichment in the mantle sources of the SVF magmas. However, similar to other volcanic rocks in the Bohemian Massif and elsewhere in the CEVP, the SVF volcanic rocks show specific fractionation patterns between the LIL and HFS elements, in particular the pronounced negative $\mathrm{K}$ anomaly in the mantle-normalized trace-element patterns (Fig. 7b). The relative depletion in $\mathrm{K}$ in the Cenozoic volcanic rocks of CEVP is often attributed to the derivation of magmas from a metasomatized mantle source, containing a residual K-rich phase, such as amphibole, at the time of magma segregation (Lustrino and Wilson 2007, and references therein). On the other hand, the relative depletion in $\mathrm{Pb}$, $\mathrm{K}$ and other LIL elements is also an inherent feature of the HIMU end-member, which is considered as a recycled oceanic crust, which suffered selective depletion in LIL elements due to dehydration during subduction (Willbold and Stracke 2006; Lustrino and Wilson 2007; Harangi et al. 2015). A detailed discussion of these issues is beyond the scope of the current paper. However, in the light of the isotopic data (Fig. 8) which indicate a very limited influence of enriched mantle end-members, and the trace-element models for magma generation calculated in this study (Fig. 10) it is considered that LILE/HFSE geochemistry of the SVF volcanic rocks may reflect the chemistry of the mantle source and the influence of the HIMU component, rather than the presence of residual 
amphibole in the mantle during the formation of the SVF magmas.

Noteworthy, in the SVF there seems also to be an association between the degree of partial meting and the degree of subsequent differentiation of the magmas: more advanced and complex differentiation is inferred for the trachybasalts, related to higher degrees of mantle melting, than for the nephelinites, produced by lower degrees of melting. It follows that larger amounts of trachybasaltic melts had a greater potential to feed more sustained magmatic systems of the trachybasaltic volcanoes, where differentiation of the primary magmas was enhanced.

\section{Conclusions - petrogenetic model of the SVF volcanism}

The relationships discussed above can be integrated into a conceptual petrogenetic model for the SVF volcanoes explaining how the interrelated processes of magma formation and differentiation influenced the composition of eruptive products and the volcanic structures formed (Tab. 5). The magma source of the SVF was dominantly in a heterogeneous asthenosphere, with mixed DM/HIMU signatures. Partial melting and segregation of magmas in rising mantle diapirs, possibly induced by regional extension (Lustrino and Wilson 2007), occurred within the garnet stability field. The heterogeneity of the mantle source was the basic cause that controlled the composition of primary magmas, also indirectly influenced subsequent differentiation processes, and finally left also some imprint on the eruptive styles. More fertile mantle domains, richer in the HIMU component, released melts at lower degrees of partial melting at greater depth. These low volumes of nephelinitic magmas underwent only limited fractional crystallization en route to the surface and erupted effusively forming lava flows or fields. In contrast, less fertile mantle domains, dominated by the DM component, released melts at higher degrees of partial melting at a shallower depth. This resulted in a more sustained magma supply that further enhanced the development of shallowlevel magmatic systems, with more advanced and complex differentiation: larger degrees of fractional crystallization as well as replenishment by new batches of primitive magma. The resulting basaltic and, especially, trachybasaltic volcanoes, showed a greater diversity of eruptive styles, including effusive and variably explosive eruptions. The volcanic structures encompass scoria cones, spatter cones and associated lavas flows. For the monogenetic volcanoes of the SVF, such evolutionary trends point to: (1) the strong coupling between the source characteristics, partial melting processes and subsequent evolution of magmas, and (2) the key role of mantle source characteristics in determining the composition of eruptive products and the style of volcanism. An additional factor must have been the interaction of rising magmas with water at near-surface levels, as evidenced by phreatomagmatic products locally found in the SVF. This phreatomagmatism, however, represented only a shallow-level modification of the deeplyrooted, mantle-related variations.

Significant geochemical variation within single monogenetic volcanoes is rather rare (e.g., Needham et al. 2011; McGee et al. 2012). However, adjacent basaltic monogenetic volcanoes in a volcanic field more commonly show distinctive geochemical characteristics (e.g., Mertes and Schmincke 1985). It is possible that the petrogenetic model for the SVF presented here, which highlights the dominant influence of deep-seated factors on the compositional diversity and eruptive behaviour

Tab. 5 A conceptual model for the Strzelin Field volcanism, highlighting the links between the deep to shallow magmatic processes, eruptive styles and compositions of different volcanic systems. Additional variation in eruptive styles may be due to phreatomagmatic activity

\begin{tabular}{|c|c|c|c|c|}
\hline & & $\begin{array}{l}\text { NEPHELINITIC } \\
\text { VOLCANOES }\end{array}$ & $\begin{array}{c}\text { BASALTIC } \\
\text { VOLCANOES }\end{array}$ & $\begin{array}{c}\text { TRACHYBASALTIC } \\
\text { VOLCANOES }\end{array}$ \\
\hline \multicolumn{2}{|c|}{ VOLCANIC STRUCTURES } & lava flows and fields & scoria cones and lava flows & scoria and spatter cones, lava flows \\
\hline \multicolumn{2}{|c|}{$\begin{array}{c}\text { DOMINANT } \\
\text { ERUPTIVE STYLE }\end{array}$} & effusive & $\begin{array}{l}\text { effusive to mildly } \\
\text { explosive }\end{array}$ & explosive to effusive \\
\hline \multicolumn{2}{|c|}{ DIFFERENTIATION PROCESSES } & $\begin{array}{l}\text { limited }(<10 \%) \text { fractional } \\
\text { crystallization of } \mathrm{Ol}>\mathrm{Cpx}\end{array}$ & $\begin{array}{l}\text { moderate }(10-15 \%) \\
\text { fractional crystallization of } \\
\qquad \mathrm{Ol}>\mathrm{Cpx}\end{array}$ & $\begin{array}{l}\text { advanced (up to } c .20 \% \text { ) fractional } \\
\text { crystallization of } \mathrm{Ol}>\mathrm{Cpx} \text { coupled } \\
\text { with replenishment by primitive } \\
\text { magma }\end{array}$ \\
\hline \multirow{3}{*}{$\begin{array}{l}\text { MELTING } \\
\text { PROCESSES AND } \\
\text { MANTLE SOURCES }\end{array}$} & $\begin{array}{l}\text { partial melting: } \\
\text { degree, melt } \\
\text { segregation depth }\end{array}$ & $\begin{array}{c}\text { c. } 0.5 \%, \\
\text { greater depth }\end{array}$ & $\begin{array}{c}\text { c. } 1 \% \text {, } \\
\text { shallower depth }\end{array}$ & $\begin{array}{c}\text { c. } 1 \% \text {, } \\
\text { shallower depth }\end{array}$ \\
\hline & source components & stronger HIMU signature & weaker HIMU signature & weakest HIMU signature \\
\hline & source characteristics & \multicolumn{3}{|c|}{$\begin{array}{l}\text { - Melt segregation within the garnet stability field } \\
\text { - Heterogeneous source, strongly dominated by DM and HIMU components relative to much } \\
\text { less important (negligible?) EM component } \\
\text { - The main magma source in the asthenosphere }\end{array}$} \\
\hline
\end{tabular}


of individual monogenetic volcanoes, may reflect more general trends, characteristic of monogenetic basaltic volcanoes and fields worldwide.

Our results show that the primary magmas of the SVF, on the eastern extremity of the CEVP, were derived from a heterogeneous, DM-HIMU-dominated mantle source, within the garnet peridotite stability field, mostly within the asthenosphere. These results are in line with those regional models of CEVP volcanism that link the origin of magmas with lithospheric extension and melting of diapirically rising asthenospheric mantle (Lustrino and Wilson 2007).

Acknowledgements. The research has been supported by internal grant 1017/S/ING from the University of Wrocław to MA and by the Czech Science Foundation through the project P210/12/1990 to VR and JM. We are indebted to the reviewers, Anna Ladenberger and Jaromír Ulrych, as well as to the Handling Editor, Emil Jelínek, and the Editor-in-Chief, Vojtěch Janoušek, for their constructive comments which lead to significant improvements of the manuscript.

Electronic supplementary material. The CIPW norms for the studied samples are available online at the Journal web site (http://dx.doi.org/10.3190/jgeosci.221).

\section{References}

Allègre CJ, Turcotte DL (1986) Implications of a twocomponent marble-cake mantle. Nature 323: 123-127

August C, Awdankiewicz M, Wojewoda J (1995) Tertiary basaltoids, volcanoclastics and sedimentary deposits in the eastern part of the Fore-Sudetic Block. Ann Soc Geol Pol - Special Volume. LXVI Annual Meeting of Polish Geological Society. Excursion guide. Polskie Towarzystwo Geologiczne, Kraków, pp 241-254

Augustín-Flores J, Siebe C, Guilbaud M-N (2011) Geology and geochemistry of Pelagatos, Cerro del Agua, and Dos Cerros monogenetic volcanoes in the Sierra Chichinautzin Volcanic Field, south of México City. J Volcanol Geotherm Res 201: 143-162

Awdankiewicz H (2008) Petrology and geochemistry of the metabasites of the Niedźwiedź Massif in the ForeSudetic Block. Pr Państw Inst Geol 189: 5-53 (in Polish, English summary)

AwdAnKiewicz M (2005) Reconstructing an eroded scoria cone: the Miocene Sośnica Hill volcano (Lower Silesia, SW Poland). Geol Q 49: 439-448

Awdankiewicz M (2013) Stop 1: Targowica, quarry of basalt. Miocene, basaltic scoria cone (structure, deposits, petrology). Min Spec Pap 41: 97-103

Badura J, Pécskay Z, Koszowska E, Wolska A, Zuchiewicz W, Przybylski B (2005) New age and petrological con- straints on Lower Silesian basaltoids, SW Poland. Acta Geodyn Geomater 2: 7-15

Bebout GE (1995) The impact of subduction-zone metamorphism on mantle-ocean chemical cycling. Chem Geol 126: 191-218

BirKENMAJER K (1967) Lower Silesian basalts as monuments of inanimate nature. Ochrona Przyrody 32: 225-276 (in Polish with English summary)

Birkenmajer K, Jerzmański J, Nairn AEM (1970) Palaeomagnetic studies of Polish rocks IV. Cenozoic basalts of Lower Silesia. Ann Soc Geol Pol 40: 31-61

Birkenmajer K, Pécskay Z, Grabowski J, Lorenc MW, ZAGOŻDŻON PP (2004) Radiometric dating of the Tertiary volcanics in Lower Silesia, Poland. IV. Further K-Ar dating and palaeomagnetic data from Late Oligocene to Early Miocene basaltic rocks of the Fore-Sudetic Block. Ann Soc Geol Pol 74: 1-19

Blusztajn J, Hart SR (1989) Sr, Nd, and Pb isotopic character of Tertiary basalts from southwest Poland. Geochim Cosmochim Acta 53: 2689-2696

Bouvier A, Blichert-Toft J, Vervoort JD, Albarède F (2005) The age of SNC meteorites and the antiquity of the Martian surface. Earth Planet Sci Lett 240: 221-233

Boynton WV (1984) Cosmochemistry of the rare earth elements: meteorite studies. In: HENDERson P (ed) Rare Earth Element Geochemistry. Elsevier, Amsterdam-New York, pp 63-114

Brenna M, Cronin SJ, Németh K, Smith IEM, Sohn YK (2011) The influence of magma plumbing complexity on monogenetic eruptions, Jeju Island, Korea. Terra Nova 23: 70-75

BüCHNER J, TiETZ O (2012) Reconstruction of the Landeskrone Scoria Cone in the Lusatian Volcanic Field, Eastern Germany - long-term degradation of volcanic edifices and implications for landscape evolution. Geomorphology 151: 175-187

Cajz V, Rapprich V, Erban V, Pécskay Z, Radoñ M (2009) Late Miocene volcanic activity in the České středohoří Mountains (Ohře/Eger Graben, northern Bohemia). Geol Carpath 60: 519-533

Cas RAF, Wright JV (1987) Volcanic Successions, Modern and Ancient: A Geological Approach to Processes, Products and Successions. Allen and Unwin, London, pp 1-528

Castro A, Fernandez C, De La Rosa JD, Moreno-Ventas I, Rogers G (1996) Significance of MORB-derived amphibolites from the Aracena metamorphic belt, southwest Spain. J Petrol 37: 235-260

Connor CB, Conway FM (2000) Basaltic volcanic fields. In: Sigurdsson H (ed) Encyclopedia of Volcanoes. Academic Press, San Diego, pp 331-343

Cwojdziński S, JodŁowski S (1982) “Stained” basaltic concentrations of the Bohemian Massif and the Lower 
Silesia. Biul Inst Geol 341: 201-229 (in Polish with English summary)

CwojDZiŃski S, WalCZAK-AugustYNiak M (1985) Detailed geological map of the Sudetes 1:25 000, sheet Niemcza. Wydawnictwa Geologiczne, Warszawa. (in Polish)

DyJor S (1995). Evolution of the Cainozoic on the ForeSudetic Block. Ann Soc Geol Pol - Special Volume. LXVI Annual Meeting of Polish Geological Society, Excursion Guide. Polskie Towarzystwo Geologiczne, Kraków, pp 29-40 (in Polish with English summary)

Geissler WH, Kämpf H, Skácelová Z, Plomerová J, BABUŠKA V, KIND R (2012) Lithosphere structure of the NE Bohemian Massif (Sudetes) - a teleseismic receiver function study. Tectonophysics 564-565: 12-37

HaAse KM, Renno AD (2008) Variation of magma generation and mantle sources during continental rifting observed in Cenozoic lavas from the Eger Rift, Central Europe. Chem Geol 257: 192-202

HARANGI S (2001) Neogene magmatism in the Alpine-Pannonian Transition Zone - a model for melt generation in a complex geodynamic setting. Acta Vulcanol 13: 25-39

Harangi S, Jankovics ME, Sági T, Kiss B, Lukács R, Soós I (2015) Origin and geodynamic relationships of the Late Miocene to Quaternary alkaline basalt volcanism in the Pannonian Basin, eastern-central Europe. Int J Earth Sci (Geol Rundsch) 104: 2007-2032

HART S (1984) A large-scale isotope anomaly in the southern Hemisphere mantle. Nature 309: 753-757

Holub FV, Rapprich V, Erban V, Pécskay Z, Mlčoch B, Míxová J (2010) Petrology and geochemistry of the Tertiary alkaline intrusive rocks at Doupov, Doupovské hory Volcanic Complex (NW Bohemian Massif). J Geosci 55: 251-278

JACOBSEN JB, WASSERBURG GJ (1980) Sm-Nd isotopic evolution of chondrites. Earth Planet Sci Lett 50: 139-155

JANOUŠEK V, FARRow CM, ERBAN V (2006) Interpretation of whole-rock geochemical data in igneous geochemistry: introducing Geochemical Data Toolkit (GCDkit). J Petrol 47: 1255-1259

Jung S, Masberg P (1998) Major- and trace-element systematics and isotope geochemistry of Cenozoic mafic volcanic rocks from the Vogelsberg (central Germany). Constraints on the origin of continental alkaline and tholeiitic basalts and their mantle sources. J Volcanol Geotherm Res 86: 151-177

Kereszturi G, Németh K (2012) Monogenetic basaltic volcanoes: genetic classification, growth, geomorphology and degradation. In: NÉMETH K (ed) Updates in Volcanology - New Advances in Understanding Volcanic Systems. In-Tech, Rijeka, pp 3-89, doi: 10.5772/51387

Kostopoulos DK, James SD (1992) Parametrization of melting regime of the shallow upper mantle and the effects of variable lithospheric stretching on mantle modal stratification and trace-element concentrations in magmas. J Petrol 33: 665-691
KozŁowski A, Wiszniewska J (eds) (2007) Granitoids in Poland. Archivum Mineralogiae Monograph, no. 1. Faculty of Geology of The Warsaw University, Warsaw, pp 1-371

Ladenberger A, Michalik M, Tomek C, Peate DW (2006) Alkaline magmatism in SW Poland - an example of asthenosphere-lithosphere interactions? Miner Pol Spec Pap 29: 40-47

Le BAS MJ (1989) Nephelinitic and basanitic rocks. J Petrol 30: 1299-1312

Le Maitre RW (ed), Streckeisen A, Zanettin B, Le Bas MJ, Bonin B, Bateman P, Bellieni G, Dudek A, Efremova S, Keller J, Lameyre J, Sabine PA, Schmid R, Sørensen H, Wooley AR (2002) Igneous Rocks. A Classification and Glossary of Terms. Recommendations of the International Union of Geological Sciences Subcommission on the Systematics of Igneous Rocks. $2^{\text {nd }}$ Edition, Cambridge University Press, CambridgeNew York, pp 1-193

Lustrino M, WiLson M (2007) The Circum-Mediterranean anorogenic Cenozoic igneous province. Earth Sci Rev 81: 1-65

Mazur S, Aleksandrowski P, Kryza R, Oberc-Dziedzic $\mathrm{T}$ (2006) The Variscan Orogen in Poland. Geol Q 50: 89-118

McDonough W, Sun SS (1995) The composition of the Earth. Chem Geol 120: 223-253

McGee LE, Millet M-A, Smith IEM, Németh K, Lindsay JM (2012) The inception and progression of melting in a monogenetic eruption: Motukorea Volcano, the Auckland Volcanic Field, New Zealand. Lithos 155: 360-374

Mertes H, Schmincke H-U (1985) Mafic potassic lavas of the Quaternary West Eifel volcanic field. Contrib Mineral Petrol 89: 330-345

Míková J, Denková P (2007) Modified chromatographic separation scheme for $\mathrm{Sr}$ and $\mathrm{Nd}$ isotope analysis in geological silicate samples. J Geosci 52: 221-226

Needham AJ, Lindsay JM, Smith IEM, Augustinus P, Shane PA (2011) Sequential eruption of alkaline and subalkaline magmas from a small monogenetic volcano in the Auckland Volcanic Field, New Zealand. J Volcanol Geotherm Res 201: 126-142

Oberc J, Dyjor S, WroŃski J (1975) Evolution of the eastern part of the Fore-Sudetic Block in Cenozoic. Przegl Geol 23: 220-223 (in Polish with English summary)

Oberc-Dziedzic T, Kryza R, Fanning MC, Klimas K, Madej S (2005) Gneiss protolith ages and tectonic boundaries in the NE part of the Bohemian Massif (Fore-Sudetic Block, SW Poland). Geol Q 49: 363-378

Oberc-Dziedzic T, Kryza R, Pin C, Madej S (2013a) Sequential granite emplacement: a structural study of the late Variscan Strzelin intrusion, SW Poland. Int J Earth Sci 102: 1289-1304

Oberc-Dziedzic T, Kryza R, Pin C, Madej S (2013b) Variscan granitoid plutonism in the Strzelin Massif (SW 
Poland): petrology and age of the composite Strzelin granite intrusion. Geol Q 57: 269-288

Oberc-Dziedzic T, KryZa R, Pin C (2015) Variscan granitoids related to shear zones and faults: examples from the Central Sudetes (Bohemian Massif) and the Middle Odra Fault Zone. Int J Earth Sci (Geol Rundsch) 104: 1139-1166

Pearce JA (1983) Role of the sub-continental lithosphere in magma genesis at active continental margins. In: Hawresworth CJ, Norry MJ (ed) Continental Basalts and Mantle Xenoliths. Nantwich, Shiva, pp 239-249

Pearce JA (1996) A user's guide to basalt discrimination diagrams. In: WyMAN DA (ed) Trace Element Geochemistry of Volcanic Rocks: Applications for Massive Sulphide Exploration. Geological Association of Canada, Short Course Notes 12: pp 79-113

Pin C, Briot D, Bassin C, Poitrasson F (1994) Concomitant separation of strontium and samarium-neodymium for isotopic analysis in silicate samples, based on specific extraction chromatography. Anal Chim Acta 298: 209-217

Puziewicz J, Czechowski L, Krysiński L, Majorowicz J, Matusiak-Malek M, Wróblewska M (2012) Lithosphere thermal structure at the eastern margin of the Bohemian Massif: a case petrological and geophysical study of the Niedźwiedź amphibolite Massif (SW Poland). Int J Earth Sci 101: 1211-1228

Puziewicz J, Matusiak-Malek M, Ntaflos T, Grégoire M, KukuŁa A (2015) Subcontinental lithospheric mantle beneath Central Europe. Int J Earth Sci (Geol Rundsch) 104: 1913-1924

RAPPRich V, Holub FV (2008) Geochemical variations within the Upper Oligocene-Lower Miocene lava succession of Úhošt' Hill (NE margin of Doupovské hory Mts., Czech Republic). Geol Q 52: 253-268

Rapprich V, Cajz V, KošŤÁk M, Pécskay Z, Řídkošil T, RAŠKA P, RADOŇ M (2007) Reconstruction of eroded monogenic Strombolian cones of Miocene age: a case study on character of volcanic activity of the Jičín Volcanic Field (NE Bohemia) and subsequent erosional rates estimation. J Geosci 52: 169-180

Rollinson HR (1993) Using Geochemical Data: Evaluation, Presentation, Interpretation. Longman Scientific \& Technical, Essex, pp 1-352

SAwicki L (ed) (1967) Geological map of the Lower Silesia region 1:200 000 (without Quaternary). Instytut Geologiczny, Warszawa (in Polish)

Schulmann K, Lexa O, Janoušek V, Lardeaux JM, Edel JB (2014) Anatomy of a diffuse cryptic suture zone: an example from the Bohemian Massif, European Variscides. Geology 42: 275-278

Silva N, Garcia I, Weis D, Barling J, Scoates JS (2009) Leaching systematics and matrix elimination for the determination of high-precision $\mathrm{Pb}$ isotope compositions of ocean island basalts. Geochem Geophys Geosys 10, doi: 10.1029/2009GC002537
Skála R, Ulrych J, Ackerman L, Jelínek E, Dostal J, Hegner E, ŘAnda Z (2014) Tertiary alkaline Roztoky Intrusive Complex, České středohoří Mts., Czech Republic: petrogenetic characteristics. Int J Earth Sci 103: 1233-1262

Steiger RH, JäGer E (1977) Subcommission on Geochronology: convention on the use of decay constants in geoand cosmochronology. Earth Planet Sci Lett 36: 359-362

Tanaka T, Togashi S, Kamioka H, Amakawa H, Kagami H, Hamamoto T, Yuhara M, Orihashi Y, Yoneda S, Shimizu H, Kunimaru T, Takahashi K, Yanagi T, Nakano T, Fujimaki H, Shinjo R, Asahara Y, Tanimizu M, DraguSANU C (2000) JNdi-1: a neodymium isotopic reference in consistency with LaJolla neodymium. Chem Geol 168: 279-281

Tietz O, Büchner J (2015) The landscape evolution of the Lausitz Block since the Palaeozoic - with special emphasis to the neovolcanic edifices in the Lausitz Volcanic Field (Eastern Germany). Z Dtsch Ges Geowiss 166: 125-147

Ulrych J, Dostal J, Adamovič J, Jelínek E, Š́paček P, HegNER E, BALOGH K (2011) Recurrent Cenozoic volcanic activity in the Bohemian Massif (Czech Republic). Lithos 123: $133-144$

Ulrych J, KRMíček L, TOMeK Č, Lloyd FE, Ladenberger A, Ackerman L, Balogh K (2016) Petrogenesis of Miocene alkaline volcanic suites from western Bohemia: whole rock geochemistry and $\mathrm{Sr}-\mathrm{Nd}-\mathrm{Pb}$ isotopic signatures. Chem Erde 76: 77-93

Wasserburg GJ, Jacobsen SB, DePaolo DJ, McCulloch MT, Wen T (1981) Precise determination of Sm/Nd ratios, Sm and Nd isotopic abundances in standard solutions. Geochim Cosmochim Acta 45: 2311-2323

Whitney DL, Evans BW (2010) Abbreviations for names of rock-forming minerals. Amer Miner 95: 185-187

Willbold M, Stracke A (2006) Trace element composition of mantle end-members: implications for recycling of oceanic and upper and lower continental crust. Geochem Geophys Geosyst 7: doi:10.1029/2005GC001005

WiLSON M (1989) Igneous Petrogenesis. Chapman \& Hall, London, pp 1-465

WiLSON M, Downes H (1991) Tertiary-Quaternary extension related alkaline magmatism in Western and Central Europe. J Petrol 32: 811-849

WiLSON M, DownEs H (2006) Tertiary-Quaternary intraplate magmatism in Europe and its relationship to mantle dynamics. In: Gee DG, Stephenson RA (eds) European Lithosphere Dynamics. Geological Society, London, Memoirs 32: 147-166

WiLson M, Downes H, CEBRIÁ JM (1995) Contrasting fractionation trends in coexisting continental alkaline magma series; Cantal, Massif Central, France. J Petrol 36: 1729-1753

Wimmenauer W (1974) The alkaline province of Central Europe and France. The alkaline rocks. In: SøRENSEN H 
(ed) Alkaline Rocks. John Wiley, London, pp 238-271

Wóscik L (1965) Detailed geological map of the Sudetes $1: 25$ 000. Sheet Kuropatnik. (in Polish)

WóscıK L (1973) Detailed geological map of the Sudetes $1: 25$ 000. Sheet Ciepłowody. (in Polish)

Wood BJ, Kiseeva ES, Matzen AK (2013) Garnet in the Earth's Mantle. Elements 9: 421-426

Workman RK, Hart SR (2005) Major and trace element composition of the depleted MORB mantle (DMM). Earth Planet Sci Lett 231: 53-72
WrońSKi J (1970a) Phenomena of Pleistocene volcanism at Dębowiec near Szklary, Lower Silesia. Kwart Geol 14: 535-547 (in Polish)

WrońsKi J (1970b) Detailed geological map of the Sudetes $1: 25$ 000. Sheet Szklary. (in Polish)

WrońsKi J (1974) Detailed geological map of the Sudetes $1: 25$ 000. Sheet Ziębice. (in Polish)

Zindler A, Hart S (1986) Chemical geodynamics. Ann Rev Earth Planet Sci 14: 493-571 